\title{
Fossil woods from early Miocene sediments of the El Cien Formation, Baja California Sur, Mexico
}

\author{
Hugo. I. Martínez-Cabrera ${ }^{a}$, Sergio R.S. Cevallos-Ferriz ${ }^{\text {b,* }}$, Imogen Poole ${ }^{c}$ \\ a Posgrado en Ciencias Biológicas, Instituto de Geología, Universidad Nacional Autónoma de México, Ciudad Universitaria, \\ Circuito de la Investigación Científica, Del. Coyoacan, 04510 México D.F., Mexico \\ b Departamento de Paleontología, Instituto de Geología, Universidad Nacional Autónoma de México, Ciudad Universitaria, \\ Circuito de la Investigación Científica, Del. Coyoacan, 04510 México D.F., Mexico \\ ${ }^{\mathrm{c}}$ Wood Anatomy Section, National Herbarium of The Netherlands, University of Utrecht Branch, P.O. Box 80102, \\ 3585 CS Utrecht, The Netherlands
}

Received 29 November 2004; received in revised form 3 December 2005; accepted 3 January 2006

Available online 20 February 2006

\begin{abstract}
Five fossil woods are described from the Miocene El Cien Formation located in Baja California Sur, Mexico. Their anatomical characters suggest affinity to the Burseraceae, Euphorbiaceae, Leguminosae and Moraceae. The fossil species described here, together with previous records, demonstrate a high familial and generic floristic similarity with the extant vegetation of western Mexico (e.g. Jalisco). This floristic link suggests a landscape dominated by a tropical deciduous or semi-deciduous forest. However, the presence of additional taxa whose living relatives thrive in relatively moist conditions today suggests a relatively humid environment. The floristic similarity between the floras growing in this region today and those existing during the Miocene can be explained by the palaeogeographic link between these two landmasses (Baja California Sur and Western Mexico) that existed until approximately 5 mybp.
\end{abstract}

(C) 2006 Elsevier B.V. All rights reserved.

Keywords: Baja California Peninsula; Miocene; El Cien Formation; fossil woods; Mexico

\section{Introduction}

Wegener (1922) hypothesized that the Peninsula of Baja California and the main American continent had a common origin. Now, after much research in the area, the tectonic events that gave rise to the present geographical configuration of Baja California are relatively well known (e.g. McKenzie and Morgan,

\footnotetext{
* Corresponding author.

E-mail addresses: hugom@geologia.unam.mx (H.I. Martínez-Cabrera), scrscfpb@servidor.unam.mx (S.R.S. Cevallos-Ferriz), i.poole@geo.uu.nl (I. Poole).
}

1969; Atwater, 1970; Mammerickx and Klitgord, 1982; Hausback, 1984). A complex series of geological events (detailed in, for example, Hausback, 1984) resulted in the severance of the Peninsula from North America, its eventual integration with the Pacific Plate, and the subsequent opening of the Gulf of California. During the deposition of sediments forming the El Cien Formation, Baja California was a structurally stable continental margin of western Mexico (McKenzie and Morgan, 1969; Atwater, 1970; Hausback, 1984). For this reason the fossil plants preserved in the El Cien Formation provide a unique opportunity to evaluate the floristic and environmental changes along the 
northwestern coast of Mexico associated with tectonic and geographic processes that have guided the evolution of this area.

Although studies of fossil floras in Mexico are somewhat limited, information determined from the macrofossil angiosperm remains have provided interesting data pertaining the biodiversity during the Cretaceous (e.g. Cevallos-Ferriz and Weber, 1992; Cevallos-Ferriz and Ricalde-Moreno, 1995; Rodríguez-de la Rosa and Cevallos-Ferriz, 1994; Hernández-Castillo and Cevallos-Ferriz, 1998; Estrada-Ruiz, 2004) and Tertiary (e.g. Magallón-Puebla and CevallosFerriz, 1993, 1994a,b,c; Velasco de León and CevallosFerriz, 1997; Velasco de León et al., 1998; RamírezGarduño, 1999; Calvillo-Canadell and Cevallos-Ferriz, 2002; Ramírez and Cevallos-Ferriz, 2002) as well as the floristic evolution (Cevallos-Ferriz and Ramírez-Garduño, 1998), continental palaeoclimates (Velasco de León, 1999) and biogeography (e.g. Ramírez et al., 2000; Martínez-Millán, 2000, 2003). This study focuses on the Baja California wood flora complementing the palaeoecological data already available and provides important new information regarding the Miocene vegetation of Mexico.

\section{Materials}

In the southern part of the Baja California Peninsula, approximately $100 \mathrm{~km}$ to the northwest of La Paz, Baja California Sur (Fig. 1), the clastic sedimentary rocks of the El Cien Formation are exposed (Applegate, 1986). The El Cien Formation is a sedimentary sequence deposited during the late Oligocene-early Miocene (Applegate, 1986; Fischer et al., 1995). It rests unconformably on the sandstone of the Tepetate Formation and is overlain by the volcanic rocks of the Comondú Formation (Applegate, 1986; Fischer et al., 1995). Although Applegate (1986), who originally proposed the El Cien Formation as a stratigraphic unit, divided it into three members, the Cerro Tierra Blanca, San Hilario and Cerro Colorado, the general consensus is that the two basal members form a single geological unit. The El Cien Formation corresponds to the (1) Monterrey Formation (Darton, 1921; Heim, 1922; Beal, 1948; Mina, 1957; Ojeda, 1959; Alatorre, 1988), (2) San Gregorio Formation (Hausback, 1984; Kim and Barron, 1986), and (3) the basal member of the El Cien Formation (San Juan Member) sensu Schwennicke (1994) and Fischer et al. (1995).

The woods described here are preserved as silica permineralizations and were collected from the upper Cerro Colorado Member of the El Cien Formation near Rancho Matanzas and Cañada El Canelo, located $5 \mathrm{~km}$ northeast and $3.5 \mathrm{~km}$ southwest from El Cien town, respectively (Fig. 1). The sediments of this Member are composed mainly of fine to coarse-grained sandstones, tuffaceous sandstones and conglomerates (Applegate, 1986; Fischer et al., 1995) and represent a progradational sequence from offshore to non-marine environments (Gidde, 1992). The change in depositional environment is evidenced by the presence of primary sedimentary structures and ichnofossils at the baseindicative of near shore environments-and by root casts of fossil plants and fossil caliche deposits towards the

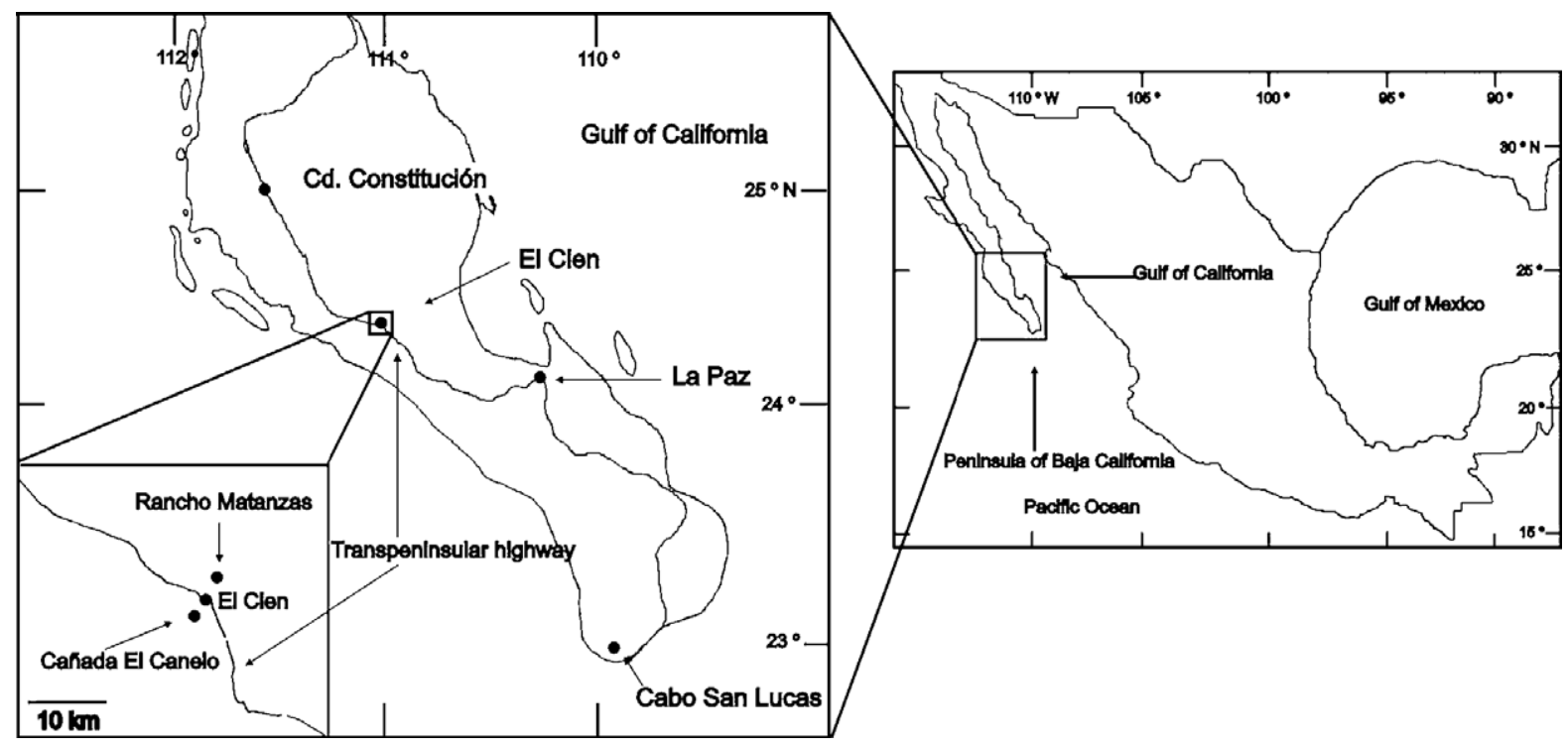

Fig. 1. Maps showing the location of the El Cien Formation and the fossil wood localities. 
top, indicating the change from lagoonal to terrestrial environments.

There has been no radiometric dating of the Cerro Colorado Member itself. However, $\mathrm{K}$-Ar radiometric dates for the underlying member give an age of 25.5 $\pm 0.4 \mathrm{my}$, whilst the overlying volcanic rocks have been dated at $21 \pm 0.4$ my (Hausback, 1984). Therefore, we assume the Cerro Colarado Member is approximately 25-20 my old.

\section{Methods}

The fossil woods were thin-sectioned in transverse, tangential and radial sections using standard techniques for petrified woods (e.g. Haas and Rowe, 1999). The descriptions of the five morphospecies are based on the observations of 19 different trees. The group of slides representing each tree is given its own IGM-LPB series number. With the exception of vessel frequency, which was calculated based on counts of 15 fields of view, the quantitative characteristics are the result of at least 25 measurements with the mean $(x)$ and standard deviation $(s)$ provided. Measurement techniques and terminology follow, in general, that described by an IAWA Committee (1989).

Familial affinities were determined by consulting reference descriptions such as Metcalfe and Chalk (1950), Détienne and Jacquet (1983), Ilic (1987, 1991), Terrazas (1994) and searches of the computerised OPCN (Wheeler et al., 1986; LaPasha and Wheeler, 1987) and CSIRO Family Key (Ilic, 1987) wood databases. Comparisons were then made with extant wood samples housed in the National Xilothec of the Institute of Biology, UNAM, and the National Herbarium of The Netherlands, Utrecht University Branch (sample numbers prefixed by Uw). All fossil specimens are deposited in the National Paleontological Collection, Institute of Geology, Universidad Nacional Autónoma de Mexico (UNAM), Mexico.

\section{Systematic palaeobotany}

\section{Family: Burseraceae}

Genus: Tetragastroxylon gen. nov.

Generic diagnosis: Fossil angiosperm wood. Vessels predominantly solitary; perforation plates simple, intervascular pits alternate, oval to polygonal, with lenticular apertures; vessel-ray pits elongated with reduced to simple borders; fibers septate; axial parenchyma absent; rays heterocellular, predominantly uniseriate, occasionally multiseriate; radial canals present in multiseriate rays.
Type species: Tetragastroxylon magniporus gen. et sp. nov. Plate I, 1-8.

Etymology: The generic name highlights the anatomical resemblance of the fossil with the wood of Tetragastris. The specific epithet reflects the large lumen of the vessels.

Holotype: LPB 259-267(ca. $4 \mathrm{~cm}$ ).

Additional material: LPB 1183-1192 (14 cm).

Repository: Paleontological Collection of the Instituto de Geología, UNAM, Mexico.

Stratigraphic horizon: Cerro Colorado Member of the El Cien Formation, early Miocene.

Locality: Rancho Matanzas, Mexico (Fig. 1).

Species diagnosis: Wood diffuse porous, growth rings indistinct; vessels solitary or in radial multiples of 2-4 with average vessel diameter $>200 \mu \mathrm{m}$; perforation plates simple, intervascular pits alternate, oval to polygonal, with lenticular apertures; vessel-ray pits with reduced to simple borders, slightly or prominently elongated; fibers septate with 1-4 septa per fiber; axial parenchyma absent; rays heterocellular, mostly uniseriate, some multiseriate ( $2-4$ cells) with one or two radial canals per ray; druses and spherical contents in radial tissue.

Description: This description is based on two pieces of wood with estimated diameters of 4 and $14 \mathrm{~cm}$. Diffuse porous wood and indistinct growth rings (Plate I, 1). Vessels circular in outline, solitary and in radial multiples of 2-4, with vessel grouping index of 1.37. Vessel element tangential diameter ranges from 140 to $327 \mu \mathrm{m}(x=226, s=45)$, length varies from 250 to $640 \mu \mathrm{m}(x=366, s=70 \mu \mathrm{m})$, wall thickness ranges from 5 to $13 \mu \mathrm{m}(x=8.6, s=1.9 \mu \mathrm{m})$, and frequency varies from (5) 7 to $16 \mathrm{~mm}^{-2}\left(x=9.5, s=2.6 \mathrm{~mm}^{-2}\right)$. Abundant thin-walled tyloses (Plate I, 1, 3). Perforation plates exclusively simple with slightly oblique end walls. Intervascular pits alternate and oval to polygonal in outline, with lenticular apertures, $4-8 \mu \mathrm{m}$ $(x=5.8, s=1.1 \mu \mathrm{m})$ in diameter. Vessel-ray pits slightly to definitely horizontally elongated with reduced or simple borders (Plate I, 7, 8). Fibers with 1-4 septate per fiber (Plate I, 3, 6), tangential diameter from 5-18 $\mu \mathrm{m}(x=12.3, s=3.6 \mu \mathrm{m})$ and wall-thickness between 1 and $4 \mu \mathrm{m}(x=2, s=1.1)$, pits not observed in fiber walls. Axial parenchyma absent (Plate I, 1). Predominantly uniseriate rays $(99 \%)$ (Plate $\mathrm{I}, 3,6), 5-11$ rays per $\mathrm{mm}$. Multiseriate rays heterocellular (Plate I, 3-6) with ray body composed of procumbent cells and 2-4 marginal rows of upright/square cells, one or two canals per ray, 50$95 \mu \mathrm{m}(x=61, s=17)$ in diameter (Plate I, 2). Uniseriate rays are $6-14(x=8.3, s=2.1)$ cells high 
and composed of procumbent and square cells. Some druses and spherical contents resembling oil drops in procumbent parenchyma cells (Plate I, 4).

Affinities:The presence of septate fibers, heterocellular rays and radial canals, plus the absence of (or very poorly developed) parenchyma suggest similarity of this fossil to the woods of Anacardiaceae and Burseraceae.
The high degree of similarity in wood characters between extant members of these two families supports the suggestion of a common ancestry for these two families based on molecular characters $(r b c \mathrm{~L})$ and morphological/anatomical analyses (Terrazas, 1994; Martínez-Millán, 2000, 2003). The high percentage of uniseriate rays in combination with the presence of
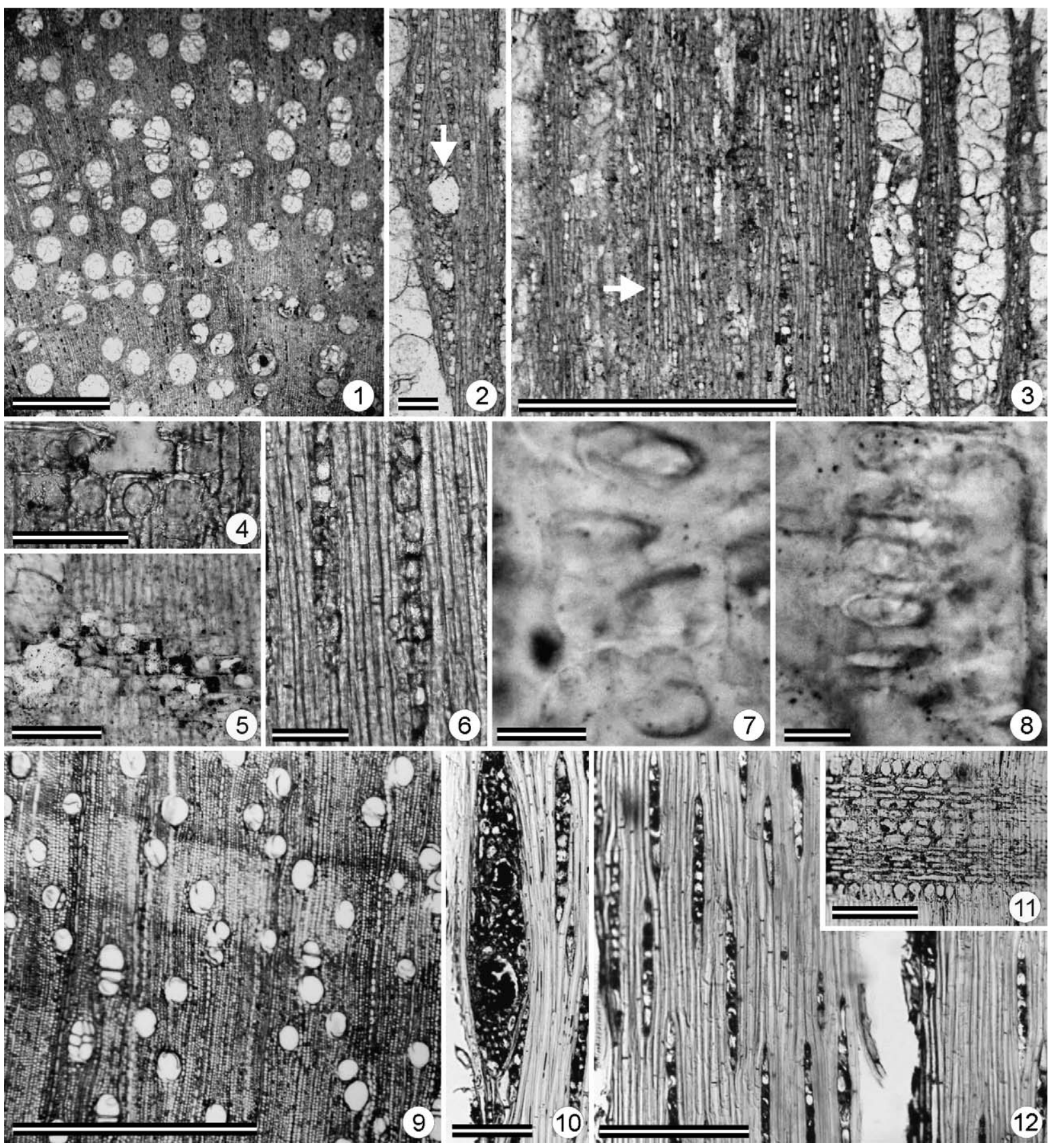

H.

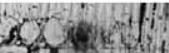

8
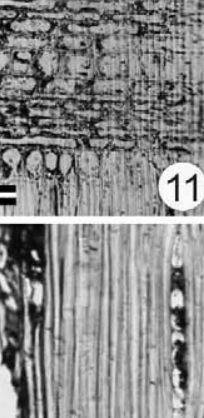
radial canals, septate fibers and absence of axial parenchyma are the most important characteristics linking the fossil wood with extant members of these families (Table 1).

In some Anacardiaceae, such as Anacardium, Swintonia (Terrazas, 1994), Gluta, Astronium and Loxopterygium, uniseriate rays dominate. However, in contrast with the fossil, Anacardium and Gluta have abundant axial parenchyma and Swintonia has nonseptate fibers (Terrazas, 1994). Some specimens of Loxopterygium (e.g. L. sagotii Uw 4239) and Astronium have high proportions of uniseriate rays (similar to those seen in the fossil wood), but differ since they are predominantly heterogeneous IIB rays (Terrazas, 1994). The presence of predominantly or exclusively uniseriate rays is relatively common in many species of Burseraceae including the majority of Dacryodes, Protium and Tetragastris species reviewed during the course of this research (Table 1).

Axial parenchyma is generally less abundant in the Burseraceae when compared with the Anacardiaceae. In particular, many species of Protium and Tetragastris (Burseraceae) have scanty paratracheal parenchyma along with exclusively uniseriate rays (Tables 1 and 2), septate fibers and radial canals (Plate I, 9-12), thus resembling the overall anatomical condition of the fossil woods. Although the number of cells per uniseriate ray in the fossil wood agrees with the number of cells per ray in Protium, the fossil wood rays are more similar to those of Tetragastris (Table 2 ) even though the size of the ray cells and proportion of square cells are greater in the fossil when compared with the two extant genera. This latter character becomes more obvious if the ratio between the number of cells and ray height is calculated. The quotient for the fossil (22) is greater than that of the extant species, T. panamensis (9) and T. altisima (11), studied. The rays in the fossil have the same frequency (2)
Table 1

Wood characteristics used in the identification of the fossil material from selected genera of Anacardiaceae and Burseraceae

\begin{tabular}{|c|c|c|c|c|}
\hline Family & Genera & $\begin{array}{l}\text { Radial } \\
\text { canals }\end{array}$ & $\begin{array}{l}\text { Uniseriate } \\
\text { rays }\end{array}$ & $\begin{array}{l}\text { Septate } \\
\text { fibers }\end{array}$ \\
\hline \multirow[t]{17}{*}{ Anacardiaceae } & Astronium (2 spp) & + & +- & + \\
\hline & Anacardium (2 spp) & - & $+(-)$ & - \\
\hline & Buchanania latifolia & - & - & - \\
\hline & $\begin{array}{l}\text { Choerospondias } \\
\text { axillaris }\end{array}$ & - & - & +- \\
\hline & Cotinus coggygria & - & - & - \\
\hline & $\begin{array}{l}\text { Cyrtocarpa } \\
\text { velutinifolia }\end{array}$ & + & - & + \\
\hline & Dracontomeloum dao & - & - & -+ \\
\hline & Gluta rhengas & + & $+(-)$ & - \\
\hline & Lannea welwitschii & + & - & - \\
\hline & $\begin{array}{l}\text { Loxopterigyum } \\
\text { sagotti }\end{array}$ & + & -+ & + \\
\hline & Mangifera indica & - & - & - \\
\hline & Pistacia chinensis & + & - & - \\
\hline & $\begin{array}{l}\text { Pseudospondias } \\
\text { microcarpa }\end{array}$ & - & - & - \\
\hline & Rhus typhina & - & - & - \\
\hline & Sclerocarya birrea & - & - & - \\
\hline & Spondias (2 spp) & + & - & - \\
\hline & $\begin{array}{l}\text { Thyrsodium } \\
\text { guianenese }\end{array}$ & + & -+ & - \\
\hline \multirow[t]{8}{*}{ Burseraceae } & Aucoumea klaineana & - & - & + \\
\hline & $\begin{array}{l}\text { Canarium } \\
\text { Shweinfurtii }\end{array}$ & - & - & + \\
\hline & Commiphora (2 spp) & + & - & + \\
\hline & Dacryodes (3 spp) & - & - & + \\
\hline & $\begin{array}{l}\text { Hemicrepidospermum } \\
\text { rhoifolium }\end{array}$ & - & $+(-)$ & + \\
\hline & Protium (12 spp) & +- & $+(-)$ & + \\
\hline & Tetragastris (3 spp) & + & $+(-)$ & + \\
\hline & Trattinickia (2 spp) & - & - & + \\
\hline
\end{tabular}

of canals per ray as seen in Tetragastris (Table 2; Plate I, 2, 10). However, there are certain anatomical differences between the fossil wood and Tetragaris and Protium to which it shows greatest similarity.

Plate I. Light micrographs of Tetragastroxylon magniporus (Figs. 1-8) and Tetragastis altissima Uw 658 (Figs. 9-12).

1. Transverse section (Ts). Diffuse porous wood and axial parenchyma absent. LPB-IGM 260. Scale bar=1 $\mathrm{mm}$.

2. Tangential section (Tg). Radial canals in a multiseriate ray. LPB-IGM 265. Scale bar $=100 \mu \mathrm{m}$.

3. Tg. Exclusively uniseriate rays and vessels filled with thin-walled tyloses. LPB-IGM 265. Scale bar=1 mm.

4. Radial section (Rs). Spherical contents in ray parenchyma cells. LPB-IGM 267. Scale bar $=100 \mu \mathrm{m}$.

5. Rs. Procumbent and square cells in the radial tissue. LPB-IGM 267. Scale bar $=150 \mu \mathrm{m}$.

6. Tg. Uniserate rays and septate fibers. LPB-IGM 266. Scale bar $=100 \mu \mathrm{m}$.

7, 8. Rs. Horizontally elongated vessel-ray pits, note the reduced borders. LPB-IGM 267. Scale bar $=10 \mu \mathrm{m}$.

9. Ts. Diffuse porous wood and scanty paratracheal axial parenchyma. Scale bar $=1 \mathrm{~mm}$.

10. Tg. Radial canals in a multiseriate rays. Scale bar $=100 \mu \mathrm{m}$.

11. Rs. Heterocellular ray. Scale bar $=150 \mu \mathrm{m}$.

12. Tg. Uniseriate rays and septate fibers. Scale bar $=150 \mu \mathrm{m}$. 
Table 2

Anatomical comparison between Tetragastroxylon magniporus and selected extant Tetragastris and Protium species exhibiting similar anatomy. $\mathrm{V}=$ vessel; $\mathrm{r}=$ rays; $\mathrm{p}=$ procumbent; $\mathrm{s}=$ square; $\mathrm{u}=$ upright

\begin{tabular}{|c|c|c|c|c|c|}
\hline Character & $\begin{array}{l}\text { Tetragastroxylon } \\
\text { magniporus }\end{array}$ & $\begin{array}{l}\text { Tetragastris altísima } \\
\text { Uw } 658\end{array}$ & $\begin{array}{l}\text { Tetragastris } \\
\text { panamensis Uw } 11062\end{array}$ & $\begin{array}{l}\text { Protium alstonii } \\
\text { Uw } 1845\end{array}$ & $\begin{array}{l}\text { Protium polybotryum } \\
\text { Uw } 4589\end{array}$ \\
\hline Porosity & Diffuse & Diffuse & Diffuse & Diffuse & Diffuse \\
\hline $\begin{array}{r}\text { Growth } \\
\text { rings }\end{array}$ & Indistinct & $\begin{array}{l}\text { Delimited by } 2-3 \\
\text { flattened latewood } \\
\text { fibers }\end{array}$ & $\begin{array}{l}\text { Weakly delimited } \\
\text { flattened latewood } \\
\text { fibers }\end{array}$ & Indistinct & Indistinct \\
\hline $\begin{array}{l}\text { V/Frequency } \\
\left(\mathrm{v} / \mathrm{mm}^{2}\right)\end{array}$ & $9.5(7-16)$ & $15.9(14-19)$ & $12.3(4-20)$ & $12.1(7-11-15)$ & $14(11-18)$ \\
\hline $\begin{array}{l}\text { Diameter } \\
\quad(\mu \mathrm{m})\end{array}$ & $225(140-327)$ & $79(56-103)$ & $98(61-124)$ & $98(67-122)$ & $105(72-139)$ \\
\hline Grouping & $1.37(77 \%$ solitary $)$ & $1.28(80 \%$ solitary $)$ & $1.32(85 \%$ solitary $)$ & $1.18(89 \%$ solitary $)$ & $1.53(77 \%$ solitary $)$ \\
\hline $\begin{array}{l}\text { Wall } \\
\text { thickness } \\
(\mu \mathrm{m})\end{array}$ & $8.6(5-13)$ & $4.2(2.9-7)$ & $3.5(2.9-6)$ & $2.8(2.3-3.4)$ & $3.2(2.3-5.8)$ \\
\hline $\begin{array}{l}\text { Intervessel pits } \\
\qquad(\mu \mathrm{m})\end{array}$ & $\begin{array}{l}\text { Alternate, oval to } \\
\text { polygonal, with } \\
\text { lenticular apertures. } \\
5.8(4-8) \text { diameter }\end{array}$ & $\begin{array}{l}\text { Alternate, oval to } \\
\text { polygonal, lenticular } \\
\text { apertures. } 6.3 \\
(4.3-8.7) \text { diameter }\end{array}$ & $\begin{array}{l}\text { Alternate, oval to } \\
\text { polygonal, lenticular } \\
\text { apertures. 5.8 } \\
\text { (3-8.7) diameter }\end{array}$ & $\begin{array}{l}\text { Alternate oval to } \\
\text { polygonal } 6.4 \\
(5.5-8.7) \text { diameter }\end{array}$ & $\begin{array}{l}\text { Alternate oval to } \\
\text { polygonal } 7 \\
(5.8-8.7) \text { diameter }\end{array}$ \\
\hline Fibers & $\begin{array}{l}\text { Septate } 1-3 \text { septa } \\
\text { per fiber }\end{array}$ & $\begin{array}{l}\text { Septate } 3-4 \text { septa } \\
\text { per fiber }\end{array}$ & $\begin{array}{l}\text { Septate } 3-4 \text { septa per } \\
\text { fiber }\end{array}$ & $\begin{array}{l}\text { Septate } 2-4 \text { septa } \\
\text { per fiber }\end{array}$ & $\begin{array}{l}\text { Septate } 3-5 \text { septa } \\
\text { per fiber }\end{array}$ \\
\hline Ray composition & $\begin{array}{l}\text { Uniseriate, } \\
\text { multiseriate less than } \\
1 \% \text {. Uniseriate rays } \\
\text { composed of } \mathrm{p} \text { and } \mathrm{s} \\
\text { cells, some } \mathrm{u} \text { cells }\end{array}$ & $\begin{array}{l}\text { Mostly uniseriate, } \\
\text { multiseriate } 18 \% \text {. } \\
\text { Uniseriate rays } \\
\text { composed of } \mathrm{p} \text {, } \\
\mathrm{s} \text { and u cells }\end{array}$ & $\begin{array}{l}\text { Mostly uniseriate, } \\
\text { multiseriate less than } \\
20 \% \text { composed of } p, \\
\mathrm{~s} \text { and } \mathrm{u} \text { cells }\end{array}$ & $\begin{array}{l}\text { Mostly uniseriate, } \\
\text { multiseriate less than } \\
10 \% \text { composed of } \mathrm{p}, \\
\mathrm{u} \text { cells, high proportion } \\
\text { of s cells (compared } \\
\text { with upright) }\end{array}$ & $\begin{array}{l}\text { Mostly uniseriate, } \\
\text { biseriate less than } \\
10 \% \text { composed of } \\
\text { p and u cells, high } \\
\text { proportion of s cells } \\
\text { (compared with u) }\end{array}$ \\
\hline $\begin{array}{l}\text { Frequency } \\
\quad(\mathrm{r} / \mathrm{mm})\end{array}$ & $7(5-11)$ & $6.4(4-9)$ & $7.9(6-11)$ & $5.2(3-4-8)$ & $5.8(4-8)$ \\
\hline $\begin{array}{l}\text { Height uniseriate } \\
\text { r (\# cells, } \mu \mathrm{m})\end{array}$ & $4-14308(145-555)$ & $\begin{array}{l}(2) 4-11(16) \\
179(70-324)\end{array}$ & $\begin{array}{l}(2) 4-17 \\
229(94-427)\end{array}$ & $3-23275(89-446)$ & (2)3-18 $242(66-381)$ \\
\hline Radial canal & $\begin{array}{l}\text { One sometimes two } \\
\text { canals per ray, } 60 \mu \mathrm{m} \\
(50-95 \mu \mathrm{m})\end{array}$ & $\begin{array}{l}\text { One sometimes two } \\
\text { canals per ray } 28 \mu \mathrm{m} \\
(23-32 \mu \mathrm{m})\end{array}$ & $\begin{array}{l}\text { One sometimes two } \\
\text { canals per ray } \\
52.6 \mu \mathrm{m}(28-66 \mu \mathrm{m})\end{array}$ & $\begin{array}{l}\text { One canal per ray } \\
89.3 \mu \mathrm{m}(70-94 \mu \mathrm{m})\end{array}$ & $\begin{array}{l}\text { One canal per ray } \\
42.3 \mu \mathrm{m}(38-47 \mu \mathrm{m})\end{array}$ \\
\hline $\begin{array}{l}\text { Vessel-ray } \\
\text { pits }\end{array}$ & $\begin{array}{l}\text { Reduced borders to } \\
\text { simple, round or } \\
\text { irregular, horizontally } \\
\text { elongated }\end{array}$ & $\begin{array}{l}\text { Reduced borders to } \\
\text { simple, round or, } \\
\text { horizontally } \\
\text { elongated }\end{array}$ & $\begin{array}{l}\text { Reduced borders to } \\
\text { simple, round or, } \\
\text { horizontally } \\
\text { elongated }\end{array}$ & $\begin{array}{l}\text { Reduced borders to } \\
\text { simple, round or, } \\
\text { horizontally elongated } \\
\text { to irregular (some) }\end{array}$ & $\begin{array}{l}\text { Reduced borders to } \\
\text { simple, round or, } \\
\text { horizontally elongated } \\
\text { to irregular (some) }\end{array}$ \\
\hline $\begin{array}{l}\text { Axial } \\
\text { parenchyma }\end{array}$ & Absent & Scanty paratracheal & Scanty paratracheal & $\begin{array}{l}\text { Scanty paratracheal } \\
\text { and diffuse apotracheal }\end{array}$ & $\begin{array}{l}\text { Scanty } \\
\text { paratracheal }\end{array}$ \\
\hline
\end{tabular}

The fossils have a higher conductive area up to two times greater the mean vessel diameter and a lower mean vessel frequency (Table 2). Another difference is the absence of axial parenchyma in the fossil material, but is present in the extant material. Even though Protium, Tetragastris and this fossil morphotype show very similar anatomical characteristics, based on the quantitative and qualitative similarities/ differences discussed above and summarised in Table 2 , the fossils are most similar anatomically to species of Tetragastris.

Several other fossil woods with anatomy similar to species of Burseraceae, and Tetragastris in particular, have been collected from Europe and Asia (e.g. Den Bergen, 1923; Dayal, 1964; Prakash et al., 1974; Prakash and Tripathi, 1975; Ghosh and Roy, 1978; 
Lakhanpal et al., 1981; Bande and Prakash, 1983; Trivedi and Srivastava, 1985; Awasthi and Srivastava, 1989; Awasthi and Mehrotra, 1993). The major distinction between the El Cien Formation fossil wood and the Asian fossil woods relates to the proportion of uniseriate rays and occurrence of axial parenchyma: Boswellioxylon indicum (Dayal, 1964) and Sumatroxylon molli (Den Bergen, 1923) have obvious axial parenchyma, few uniseriate rays and multiseriate rays up to 6 cells wide. Species of Burseroxylon ( $B$. preserratum and B. garugoides; Prakash and Tripathi, 1975; Lakhanpal et al., 1981, respectively) lack radial canals, have axial parenchyma and predominantly multiseriate rays. In Canarioxylon ceskobudejovicense (Prakash et al., 1974), from Czech Republic, and $C$. indicum from India (Ghosh and Roy, 1978), radial canals are absent. Awasthi and Srivastava (1989) describe a wood, Canarium palaeoluzonicum, from the Neogene flora of the Kerala Basin that they believe is related to Canarium. This has great similarity with the fossil from El Cien Formation; although, Canarium palaeoluzonicum (Awasthi and Srivastava, 1989) has a high frequency of uniseriate rays, they are more abundant (>90\%) in the fossil from the El Cien Formation.

The absence of axial parenchyma in the fossil woods described here, coupled with the particularly high incidence of the uniseriate rays and its closer similarity to extant members of Protium and particularly Tetragastris (Burseraceae) than to fossil burseraceous woods previously described, support the erection of a new morphogenus.

\section{Family: Euphorbiaceae}

Genus: ParaphyllanthoxylonBailey (1924)

Species: Paraphyllanthoxylon mennegae sp. nov. Plate II, $1-8$.

Etymology: The specific epithet is after A.M.W. Mennega in recognition of her work on the wood anatomy of the Euphorbiaceae.

Holotype: LPB 227-258 (4 cm).

Additional material: LPB 4120-4134 (ca. $6 \mathrm{~cm}$ ); LPB 4203-4217 (ca. 9.5 cm); LPB 3573-3574 (10.5 cm); LPB 982-989, 991, 993-1000 (ca. $6.2 \mathrm{~cm}$ ).

Repository: Paleontological Collection of the Instituto de Geología, UNAM, Mexico.

Stratigraphic horizon: Cerro Colorado Member of the El Cien Formation, early Miocene.

Locality: Rancho Matanzas (LPB 227-258; LPB 982989, 991, 993-1000) and Cañada El Canelo (LPB 4120-4134; LPB 4203-4217; LPB 3573-3574), Mexico (Fig. 1).
Species diagnosis: Diffuse porous, growth rings indistinct; vessels solitary or in radial multiples of 24 (5) with average tangential diameter $<100 \mu \mathrm{m}$; perforation plates simple, intervascular pits alternate, oval to polygonal; vessel-ray pits oval to irregularly shaped, horizontally elongated to scalariform; 2-3 septa per fiber; axial parenchyma absent; rays heterocellular, uniseriate and multiseriate; uniseriate rays composed exclusively of upright cells, 4-14 cells high; multiseriate rays $2-3$, exceptionally 4 cells wide, $<1500 \mu \mathrm{m}$ high and composed predominantly of upright and square cells with few procumbent cells; uniseriate margins composed of 1-6 cells.

Description: This description is based on five pieces of wood with estimated diameters ranging from 4 to 10.5 $\mathrm{cm}$. Diffuse porous wood with indistinct growth rings. Vessels oval in cross section, solitary and in radial multiples of 2-4 (5), with 1.8 vessels per group (Plate II, 1). Vessel element tangential diameter ranges from 40 to $97.5 \mu \mathrm{m}(x=71 \mu \mathrm{m}, s=16)$, length varies from 215 to $795 \mu \mathrm{m}(x=469 \mu \mathrm{m}, s=120)$, wall thickness ranges from 2 to $5 \mu \mathrm{m}(x=3.2 \mu \mathrm{m}, s=0.88)$, and frequency varies from 23 to $66 \mathrm{~mm}^{-2}\left(x=45.9 \mathrm{~mm}^{-2}, s=10\right)$. Perforation plates simple with oblique end walls (Plate II, 5). Intervascular pits oval and alternate with circular or elliptic apertures (Plate II, 7), 3-7 $\mu \mathrm{m}(x=4.8 \mu \mathrm{m}$, $s=1.1)$ in diameter. Vessel-ray pits horizontally elongated with reduced to simple borders (Plate II, 4, 6). Thinwalled tyloses. Fibers with 2-3 septa per fiber (Plate II, $2,3,8)$. Fiber tangential diameter ranges from 6 to $24 \mu \mathrm{m}$ $(x=13.6 \mu \mathrm{m}, s=5.5)$ and wall-thickness varies from 1 to $8 \mu \mathrm{m}(x=4.1 \mu \mathrm{m}, s=1.6)$. Axial parenchyma absent. Ray frequency 6-9 per $\mathrm{mm}(x=7.5$ per $\mathrm{mm}, s=0.83 / \mathrm{mm})$. Rays heterocellular (Plate II, 2-4, 8), uniseriate and multiseriate. Multiseriate rays 2-3 (-4) cells wide and $310-1450 \mu \mathrm{m}(x=755 \mu \mathrm{m}, s=316 \mu \mathrm{m})$ high. Body of multiseriate rays composed of predominantly square and upright cells, with uniseriate extensions composed of 1$6(x=2.4, s=1.3)$ rows of upright cells. Uniseriate rays composed entirely of upright cells, $4-14(x=6.5, s=2.9)$ cells high. Dark contents in ray cells common.

Species: Paraphyllanthoxylon coloradensis sp. nov. Plate III, 1-8.

Etymology: The specific epithet reflects the geologic unit from which the fossils were collected.

Holotype: LPB 1044-1063 (5.4 cm).

Additional material: LPB 3585 (ca. $7 \mathrm{~cm}$ ); LPB 1002$1004(7.5 \mathrm{~cm})$; LPB 1196-1204 (2.2 cm); LPB 11741182 (ca. $14 \mathrm{~cm})$.

Repository: Paleontological Collection of the Instituto de Geología, UNAM, Mexico. 
Stratigraphic horizon: Cerro Colorado Member of the El Cien Formation, early Miocene.

Locality: Rancho Matanzas (LPB 1044-1063; LPB 1002-1004. LPB 1196-104. LPB 1174-1182) and Cañada El Canelo (LPB 3585), Mexico (Fig. 1).
Species diagnosis: Wood diffuse porous, growth rings indistinct; vessels solitary or in radial multiples of 2-4, sometimes more, average tangential diameter $>100 \mu \mathrm{m}$; perforation plates simple, intervascular pitting alternate, oval to polygonal; vessel-ray pits horizontally elongated
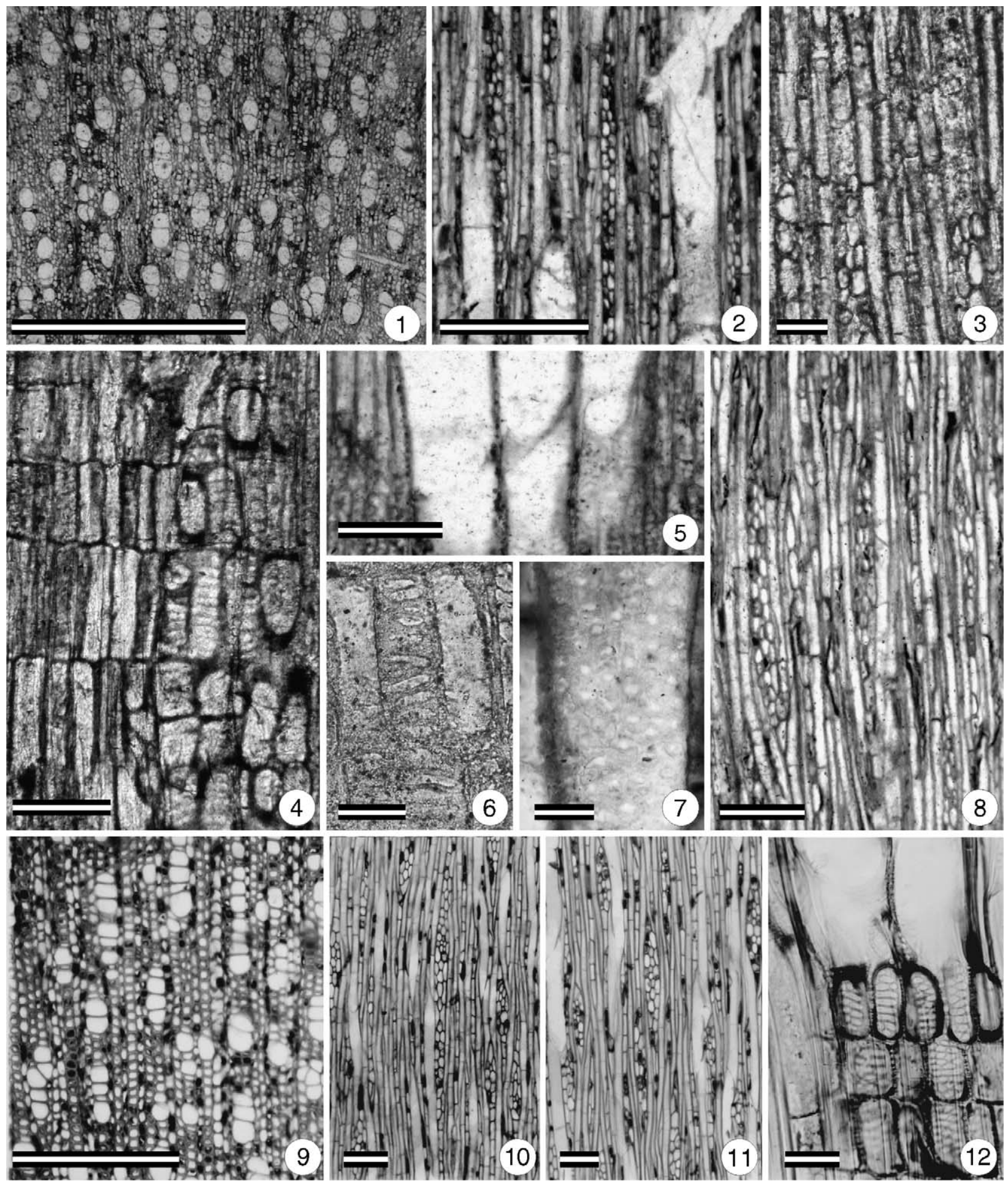
to scalariform; fibers septate, 2-3 septa per fiber, or nonseptate; axial parenchyma absent; rays uniseriate and multiseriate; uniseriate rays homocellular composed exclusively of upright cells, 3-14 cells high; multiseriate rays heterocellular, 2-3 cells wide and up to $3400 \mu \mathrm{m}$ high, composed predominantly of procumbent cells with some upright and square cells; some rays have biseriate and uniseriate portions within a constant width, and uniseriate margins $1-8$ cells high.

Description: This description is based on five pieces of wood with estimated diameters of $\sim 2$ to $14 \mathrm{~cm}$. Diffuse porous wood with indistinct growth rings (Plate III, 1). Vessels in cross section oval, solitary and in radial multiples of 2-4, sporadically longer, vessel grouping index of 1.58. Vessel element tangential diameter varies from 75 to $185 \mu \mathrm{m}(x=131 \mu \mathrm{m}, s=23.6 \mu \mathrm{m})$, length ranges from 410 to $830 \mu \mathrm{m}(x=627 \mu \mathrm{m}, s=124 \mu \mathrm{m})$, wall-thickness between 2 and $6 \mu \mathrm{m}(x=3.5 \mu \mathrm{m}$, $s=1.1$ ), and frequency ranges from 15 to $36 \mathrm{~mm}^{-2}$ $\left(x=24.4 \mathrm{~mm}^{-2}, s=5.9\right)$. Perforation plates simple with oblique end walls (Plate III, 7, 8). Intervascular pits oval to polygonal, alternate, and $10-13 \mu \mathrm{m}(x=11.5$ $\mu \mathrm{m}, s=1)$ in diameter. Vessel-ray parenchyma pits horizontally elongate, with simple to reduced borders (Plate III, 5, 6). Thin-walled tyloses. Fibers with 2-3 septa per fiber, or non-septate (Plate III, 2-4), with tangential diameter ranging from 10 to $28 \mu \mathrm{m}(x=18.2$ $\mu \mathrm{m}, s=5.6)$ and wall-thickness varies from 1 to $6 \mu \mathrm{m}$ $(x=2 \mu \mathrm{m}, s=1.4)$. Axial parenchyma absent (Plate III, 1). Rays uniseriate and multiseriate (Plate III, 2-4), with frequency of $5-11$ per $\mathrm{mm}(x=8.1$ per $\mathrm{mm}$, $s=1.6$ ). Multiseriate rays heterocellular, 2-3 cells wide and 600-3400 $\mu \mathrm{m}(x=1586 \mu \mathrm{m}, s=624)$ high, with body composed predominantly of procumbent cells although upright and square cells can be present. Uniseriate extensions of multiseriate rays composed of $1-8 \quad(x=4.1, s=2.1)$ upright cells. Uniseriate rays homocellular, 3-14 $(x=7.5, s=2.6)$ cells high and composed exclusively of upright cells. Some rays have alternating biseriate and uniseriate portions with constant width.

Affinities: The Paraphyllanthoxylon wood type was first described by Bailey (1924) and the organ genus has been used repeatedly for fossil woods characterised by weakly differentiated growth rings, simple perforation plates, alternate intervascular pits, large vessel-ray pits, scanty to absent axial parenchyma, septate fibers, heterocellular rays and tyloses. The fossil woods described here fit well with the suite of diagnostic characters given above and thus the woods are assigned to Paraphyllanthoxylon. The two morphotypes from the El Cien Formation can be separated based on the relative vessel diameter, amount of septate fibers, multiseriate ray height and cellular composition and the presence of uniseriate and biseriate portions in some rays with constant ray width.

The Paraphyllanthoxylon wood type is common in the sedimentary record, both in time and space (e.g. Bailey, 1924; Spackman, 1948; Mädel, 1962; Prakash, 1958; Cahoon, 1972; Thayn et al., 1983; Prakash et al., 1986; Wheeler et al., 1987, 1995; Wheeler, 1991; Herendeen, 1991; Cevallos-Ferriz and Weber, 1992; Meijer, 2000). The anatomy exhibited by Paraphyllanthoxylon is commonly associated with that of Anacardiaceae, Burseraceae, Elaeocarpaceae, Euphorbiaceae, Flacourtiaceae and Lauraceae, amongst others. While many authors accept that the anatomy of Paraphyllanthoxylon is closest to the Euphorbiaceae (Mädel, 1962; Privé, 1975; Thayn et al., 1983; Thayn and Tidwell, 1984; Prakash et al., 1986), not all researchers agree in considering the similarity enough to assign it to this family (Bailey, 1924; Spackman, 1948; Cahoon, 1972; Wheeler, 1991).

Based on the occurrence and number of marginal cells associated with the multiseriate rays and the amount of the uniseriate rays, Wheeler et al. (1987) and Herendeen (1991) recognise two anatomical groups within Paraphyllanthoxylon: (1) those Paraphyllanthoxylon species

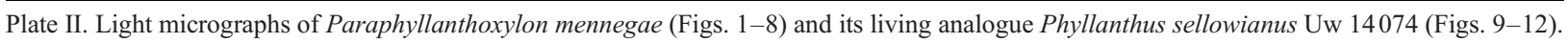

1. Ts. Diffuse porous wood, mostly radial multiples of two cells and axial parenchyma absent. LPB-IGM 227. Scale bar=1 mm.

2, 8. Tg. 1-3 seriate heterocellular rays and septate fibers. LPB-IGM 238. Scale bar $=300 \mu \mathrm{m}, 100 \mu \mathrm{m}$ respectively.

3. Tg. Septate fibers. LPB-IGM 238. Scale bar $=50 \mu \mathrm{m}$.

4. Rs. Heterocellular ray, note the upright cells and the scalariform vessel-ray pitting. LPB-IGM 243. Scale bar $=50 \mu \mathrm{m}$.

5. Rs. Simple perforation plates. LPB-IGM 243. Scale bar $=70 \mu \mathrm{m}$.

6. Rs. Oval to horizontally elongated vessel-ray pits. LPB-IGM 4209. Sacle bar $=20 \mu \mathrm{m}$.

7. Rs. Alternate intervascular pitting. LPB-IGM 4209. Scale bar $=20 \mu \mathrm{m}$

9. Ts. Long radial multiples. Scale bar $=500 \mu \mathrm{m}$.

10, 11. Tg. Heterocellular and septate fibers. Scale bar $=100 \mu \mathrm{m}$

12. Rs. Oval to scalariform vessel-ray pits in upright cells. Scale bar $=50 \mu \mathrm{m}$. 

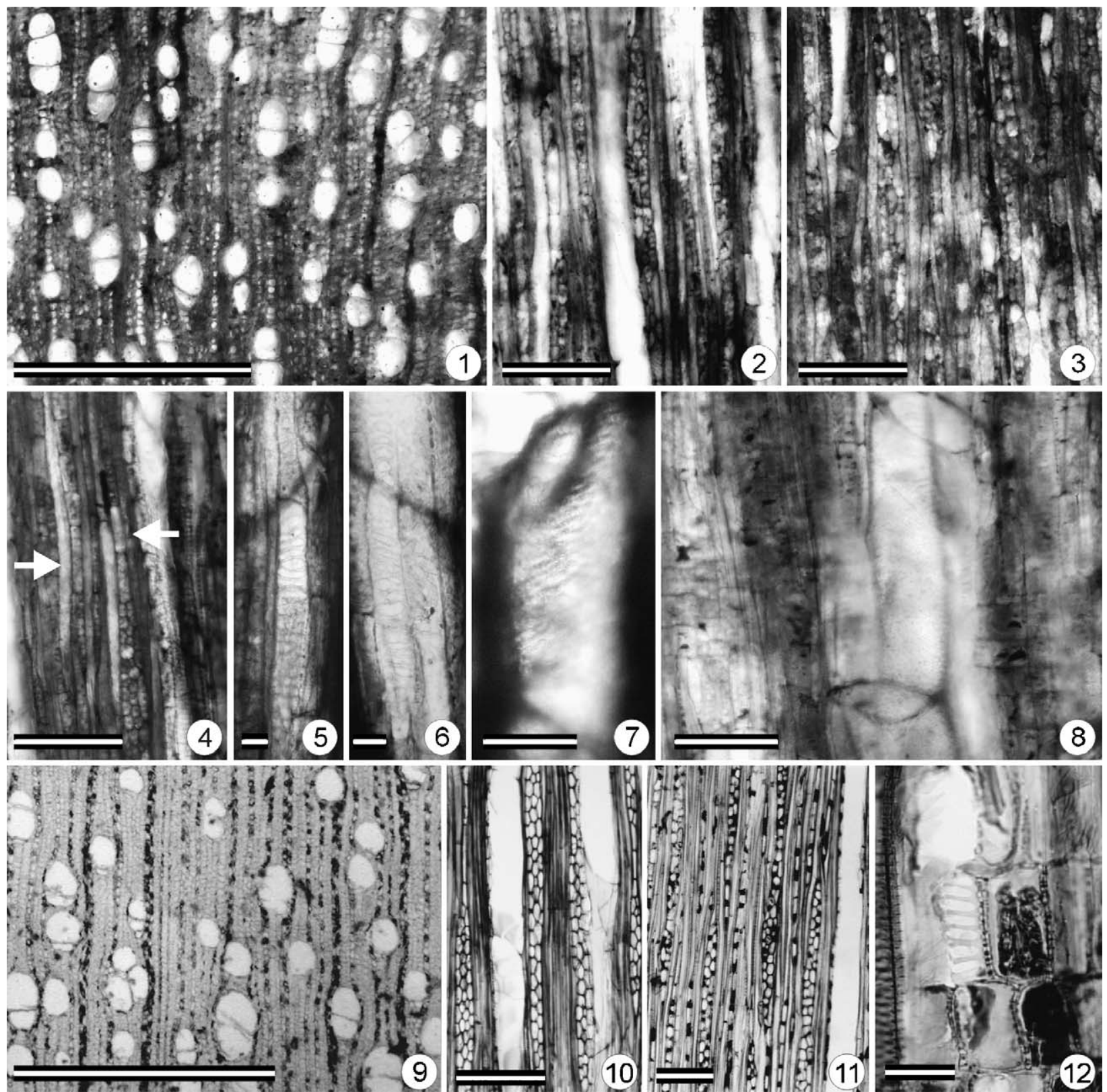

Plate III. Light micrographs of Paraphyllanthoxylon coloradensis (Figs. 1-8), Fluggea flexuosa Uw 24716 (Fig. 9), Phyllanthus juglandifolius Uw 31189 (Fig. 10), Antidesma pulvinatum Uw 31193 (Fig. 11), Hymenocardia wallichii Uw 14634 (Fig. 14634)

1. Ts. Diffuse porous wood. LPB-IGM 1044. Scale bar=1 mm.

2, 3. Tg. Heterocellular rays and non-septate fibers. LPB-IGM 1052. Scale bar $=300 \mu \mathrm{m}$.

4. Tg. The arrows show a long uniseriate tail (right) and a non-septate fiber. LPB-IGM 1052. Scale bar $=300 \mu \mathrm{m}$.

5. Tg. Scalariform vessel-ray pits in uniseriate ray cells. LPB-IGM 1054. Scale bar $=30 \mu \mathrm{m}$.

6. Rs. Oval to scalariform vessel-ray pits. LPB-IGM 1059. Scale bar $=30 \mu \mathrm{m}$.

7. Rs. Simple perforation plate. LPB-IGM 1059. Scale bar $=70 \mu \mathrm{m}$.

8. Rs. Rays with procumbent, square and upright cells; vessels with simple perforation plates. LPB-IGM 1062. Scale bar=100 $\mu \mathrm{m}$

9. Ts. Diffuse porous wood, scanty paratracheal parenchyma. Scale bar $=1 \mathrm{~mm}$.

10, 11. Tg. Heterocellular rays. Scale bar $=200 \mu \mathrm{m}$.

12. Rs. Scalariform vessel-ray pits in upright cells. LPB-IGM 243. Scale bar $=30 \mu \mathrm{m}$. 
with few, short marginal extensions in the multiseriate rays and few or rare uniseriate rays ( $P$. utahense, $P$. idahoense, $P$. marylandense, $P$. alabamense, $P$. capense) have greater affinity with Lauraceae, Elaeocarpaceae, Anacardiaceae, Burseraceae and Verbenaceae; and (2) Paraphyllanthoxylon species with abundant uniseriate rays and long uniseriate extensions of the multiseriate rays (i.e. $P$. arizonense and $P$. illinoisense) are anatomically closer to Ulmaceae, Flacourtiaceae, Euphorbiaceae and Simaroubaceae (Herendeen, 1991). It is, therefore, possible that Paraphyllanthoxylon represents more than a single taxonomic group (Herendeen, 1991; Wheeler, 1991). By comparing the wood of $P$. marylandense (of group 1) with the xylem of the inflorescence axis of Mauldinia mirabilis, Herendeen (1991) demonstrated that closest anatomical similarity of this morphospecies lies with the Lauraceae. In contrast, Wheeler et al. (1987) consider the markedly heterocellular condition of the rays exhibited by $P$. arizonense and P. illinoisense (group 2) as indicative of anatomical similarity to the Euphorbiaceae. However, Wheeler et al. (1987) also stated that these Paraphyllanthoxylon species also resemble the Flacourtiaceae and Violaceae in other characters.

When the fossil woods from El Cien Formation are compared with the two groups of Paraphyllanthoxylon, it is clear that the fossils are anatomically closer to group 2 since they share long uniseriate margins in multiseriate rays and abundant uniseriate rays. From a comparison of these fossil woods with the wood from the extant families listed above, closest anatomical similarity is found with members of Euphorbiaceae and Flacourtiaceae which also exhibit a combination of septate fibers, heterocellular rays (heterogeneous Kribs type I), multiseriate rays with large uniseriate extensions, absence of axial parenchyma (or scanty paratracheal), simple perforation plates, alternate intervessel pits and large vessel-ray pits.

Similarity can be recognised in some genera within the Gloichidion group. For example, Bischoffia, Phyllanthus and Antidesma are difficult to distinguish from Caloncoba in the Euphorbiaceae, or Erythrospermum and Kiggelaria of the Flacourtiaceae (Metcalfe and Chalk, 1950; Miller, 1975). Miller (1975) also noted the similarity of other Euphorbiaceae taxa (Acalypha, Aporocella, Gloichidion and Hymenocardia) to members of the Flacourtiaceae genera in the subtribes Casearieae and Homalieae. The suite of characters listed above is common to all Flacourtiaceae (Miller, 1975), but in Euphorbiaceae they are restricted to certain groups such as the Phyllanthoidae (especially the Gloichidion group; Metcalfe and Chalk, 1950; Men- nega, 1987). The combination of (i) simple perforation plates, (ii) exclusively alternate intervascular pits, and (iii) ray-vessel pits large, oval, irregular and/or horizontally elongated with a scalariform pattern, along with the features already mentioned above, restricts the similarity of the fossil woods to different tribes within Flacourtiaceae (i.e. Ahernia [Berberidopsideae], Oncoba and Lindackeria [Oncobeae], Pineda [Banareae], Poliothyrsis and Itoa [Flacourtiaeae]) and Euphorbiaceae (i.e. Spondiantheae, Antidesma, Phyllantheae-only Flueggeinae-, Hymenocardieae and Bischofieae) (Miller, 1975).

In Flacourtiaceae the ground tissue is composed either of tracheids, or both fiber-tracheids and/or libriform fibers which are predominantly septate (Miller, 1975). In contrast, but with the exception of Hyeronima (Mennega, pers. com., 2003), the ground tissue of the Phyllanthoideae is almost always composed of libriform fibers. Therefore, those Flacourtiaceae with fiber-tracheids forming the ground tissue may be excluded from further discussion. Those members of the Flacourtiaceae with exclusively libriform fibers (such as Trimeria, Scolopia, Grossypiospermum, Ophiobotrys, Neoptychocarpus) can also be distinguished from the El Cien Paraphyllanthoxylon fossils based on the small rayvessel pits that are similar to the intervessel pits. Therefore, the new fossils share greater anatomical similarity with the Euphobiaceae, and in particular with Phyllanthoideae.

Within the Phyllanthoideae two different anatomical types can be distinguished: (1) the Gloichidion type and (2) the Aporusa type (Metcalfe and Chalk, 1950; Mennega, 1987). These types can be distinguished by the presence of predominantly simple perforation plates, thin-walled septate fibers, and either no axial parenchyma or very scarce paratracheal parenchyma in the Gloichidion type (Mennega, 1987). The anatomical pattern of the fossils has greatest similarity to the Gloichidion group and Antidesma (anatomically similar to the Gloichidion group but belonging to the Aporusa wood type). Within the Gloichidion group, Spondiantheae, Bischofieae, Dicoelieae and Bridelieae can be distinguished from the other tribes and the El Cien Formation fossils based on their relatively wide (in terms of cell numbers) multiseriate rays, whilst Poranthereae and Uapaceae differ in having exclusively non-septate libriform fibers (Mennega, 1987). Securinega of the tribe Phyllantheae can also be eliminated because of the presence of exclusively scalariform perforation plates, vessel-ray pits similar to intervascular pits and abundant axial parenchyma. Both El Cien Paraphyllanthoxylon fossil types share characters with 
Table 3

Anatomical comparison of Paraphyllanthoxylon coloradensis and Paraphyllanthoxylon mennegae with selected extant members of the subfamily Phyllanthoideae exhibiting similar anatomy. N, number of cells; O, oval; I, irregular; He, horizontally elongated; S, scalariform; Oe, oblique elongated; s/f, septa per fiber

\begin{tabular}{|c|c|c|c|c|c|c|c|c|c|c|c|}
\hline Character & $\begin{array}{l}\text { Antidesma } \\
\text { membranaceaous } \\
\text { Uw } 15897\end{array}$ & $\begin{array}{l}\text { Antidesma } \\
\text { montanum } \\
\mathrm{Uw} 31312\end{array}$ & $\begin{array}{l}\text { Antidesma } \\
\text { pulvinatus } \\
\text { Uw } 31193\end{array}$ & $\begin{array}{l}\text { Margaritaria } \\
\text { indica Uw } \\
10905\end{array}$ & $\begin{array}{l}\text { Hymenocardia } \\
\text { walichii Uw } \\
14634\end{array}$ & $\begin{array}{l}\text { Fluggea } \\
\text { flexuosa } \\
\text { Uw } 24716\end{array}$ & $\begin{array}{l}\text { Phyllanthus } \\
\text { juglandiflolius } \\
\text { Uw } 31189\end{array}$ & $\begin{array}{l}\text { Phyllanthus } \\
\text { grandifolius } \\
\text { Uw } 875\end{array}$ & $\begin{array}{l}\text { Phyllanthus } \\
\text { sellowianus } \\
\text { Uw } 14074\end{array}$ & $\begin{array}{l}\text { Paraphyllanthoxylon } \\
\text { coloradensis }\end{array}$ & $\begin{array}{l}\text { Paraphyllanthoxylon } \\
\text { mennegae }\end{array}$ \\
\hline $\begin{array}{l}\text { Vessel } \\
\quad \text { diameter } \\
(\mu \mathrm{m})\end{array}$ & $\begin{array}{l}56-94 \\
(75)\end{array}$ & $\begin{array}{l}28-51 \\
(36)\end{array}$ & $\begin{array}{l}47-94 \\
(69)\end{array}$ & $\begin{array}{l}61-136 \\
(93)\end{array}$ & $\begin{array}{l}32-51 \\
(43)\end{array}$ & $\begin{array}{l}94-136 \\
(114)\end{array}$ & $\begin{array}{l}61-141 \\
(101)\end{array}$ & $\begin{array}{l}70-117 \\
(92)\end{array}$ & $\begin{array}{l}34-85 \\
(63)\end{array}$ & $\begin{array}{l}75-170 \\
(129)\end{array}$ & $\begin{array}{l}40-97 \\
(71)\end{array}$ \\
\hline $\begin{array}{l}\text { Intervascular } \\
\text { pits diameter } \\
(\mu \mathrm{m})\end{array}$ & 6 & $6-9$ & $6-12$ & $6-15$ & 6 & $3-4$ & $6-9$ & $6-12$ & $6-8$ & $6-13$ & $5-9$ \\
\hline $\begin{array}{l}\text { Height of } \\
\text { multiseriate } \\
\text { rays }(\mu \mathrm{m})\end{array}$ & $\begin{array}{l}729-4680 \\
(2225)\end{array}$ & $\begin{array}{l}648-2640 \\
(1424)\end{array}$ & $\begin{array}{l}480-2280 \\
(1093)\end{array}$ & $\begin{array}{l}468-2064 \\
(968)\end{array}$ & $\begin{array}{l}720-2280 \\
(1471)\end{array}$ & $\begin{array}{l}480-1920 \\
(1187)\end{array}$ & $\begin{array}{l}420-3240 \\
(1466)\end{array}$ & $\begin{array}{l}864-2760 \\
(1720)\end{array}$ & $\begin{array}{l}348-984 \\
(634)\end{array}$ & $\begin{array}{l}600-3400 \\
(1586)\end{array}$ & $\begin{array}{l}310-1450 \\
(755)\end{array}$ \\
\hline $\begin{array}{l}\text { Uniseriate } \\
\text { extensions } \\
(\mu \mathrm{m})\end{array}$ & $\begin{array}{l}72-1440 \\
(530)\end{array}$ & $\begin{array}{l}60-900 \\
(356)\end{array}$ & $\begin{array}{l}60-624 \\
(304)\end{array}$ & $\begin{array}{l}108-468 \\
(252)\end{array}$ & $\begin{array}{l}144-504 \\
(341)\end{array}$ & $\begin{array}{l}48-840 \\
(345)\end{array}$ & $\begin{array}{l}84-1080 \\
(245)\end{array}$ & $\begin{array}{l}180-1560 \\
(482)\end{array}$ & $\begin{array}{l}36-300 \\
(165)\end{array}$ & $\begin{array}{l}110-1100 \\
(458)\end{array}$ & $\begin{array}{l}35-580 \\
(143)\end{array}$ \\
\hline $\begin{array}{l}\text { Uniseriate } \\
\text { extensions } \\
(N)\end{array}$ & $\begin{array}{l}1-16 \\
(5.9)\end{array}$ & $\begin{array}{l}1-14 \\
(6.8)\end{array}$ & $\begin{array}{l}1-12 \\
(5.4)\end{array}$ & $\begin{array}{l}2-10 \\
(5.3)\end{array}$ & $\begin{array}{l}3-12 \\
(6)\end{array}$ & $\begin{array}{l}1-14 \\
(5.9)\end{array}$ & $\begin{array}{l}1-16 \\
(4)\end{array}$ & $\begin{array}{l}2-19 \\
(6)\end{array}$ & $\begin{array}{l}1-6 \\
(3)\end{array}$ & $1-8(4)$ & $\begin{array}{l}1-6 \\
(2.4)\end{array}$ \\
\hline $\begin{array}{l}\text { Height of } \\
\text { uniseriate } \\
\text { rays }(\mu \mathrm{m})\end{array}$ & $\begin{array}{l}132-1680 \\
(871)\end{array}$ & $\begin{array}{l}156-1080 \\
(552)\end{array}$ & $\begin{array}{l}216-792 \\
(526)\end{array}$ & $\begin{array}{l}132-480 \\
(310)\end{array}$ & $\begin{array}{l}180-1200 \\
(598)\end{array}$ & $\begin{array}{l}180-1080 \\
(472)\end{array}$ & $\begin{array}{l}180-1008 \\
(485)\end{array}$ & $\begin{array}{l}240-1200 \\
(563)\end{array}$ & $\begin{array}{l}252-1250 \\
(384)\end{array}$ & $\begin{array}{l}310-1300 \\
(808)\end{array}$ & $\begin{array}{l}190-700 \\
(361)\end{array}$ \\
\hline $\begin{array}{l}\text { Height of } \\
\text { uniseriate } \\
\text { rays }(N)\end{array}$ & $2-18(9)$ & $\begin{array}{l}2-19 \\
(9.4)\end{array}$ & $\begin{array}{l}2-17 \\
(10)\end{array}$ & $\begin{array}{l}3-11 \\
(7)\end{array}$ & $\begin{array}{l}6-22 \\
(11)\end{array}$ & $\begin{array}{l}2-19 \\
(8)\end{array}$ & $\begin{array}{l}3-20 \\
(8)\end{array}$ & $\begin{array}{l}3-15 \\
(8.3)\end{array}$ & $\begin{array}{l}4-10 \\
(7.5)\end{array}$ & $\begin{array}{l}3-14 \\
(7.5)\end{array}$ & $\begin{array}{l}4-14 \\
(6.5)\end{array}$ \\
\hline Rays per mm & 7.6 & 14.5 & 12.5 & 13 & 14 & 11.8 & 6.3 & 5.6 & 10.1 & 8.1 & 7.5 \\
\hline Ray width $(N)$ & $2-3(2)$ & $2-3(2)$ & $2-3(2)$ & $2-3(2)$ & $2-4(2-3)$ & $2-4(3)$ & $2-4(2-3)$ & $2-4(2-3)$ & $2-4(2-3)$ & $2-3$ & $2-4(2-3)$ \\
\hline Vessel-ray pits & $\mathrm{O}, \mathrm{I}, \mathrm{He}, \mathrm{S}$. & $\mathrm{O}, \mathrm{I}, \mathrm{He}, \mathrm{S}$ & $\mathrm{O}, \mathrm{I}, \mathrm{He}, \mathrm{S}$ & $\begin{array}{l}\text { O, some } \\
\text { slightly } \\
\text { elongated }\end{array}$ & $\mathrm{O}, \mathrm{I}, \mathrm{He}, \mathrm{S}$ & $\mathrm{O}, \mathrm{I}, \mathrm{He}, \mathrm{S}$ & $\begin{array}{l}\mathrm{O}, \mathrm{I}, \mathrm{He} \\
\mathrm{S} \text { to } \mathrm{Oe}\end{array}$ & $\mathrm{O}, \mathrm{I}, \mathrm{He}, \mathrm{S}$ & $\mathrm{O}, \mathrm{I}, \mathrm{He}, \mathrm{S}$ & $\mathrm{O}, \mathrm{I}, \mathrm{He}, \mathrm{S}$ & $\mathrm{O}, \mathrm{I}, \mathrm{He}, \mathrm{S} \mathrm{E}$ \\
\hline Sheath cells & Present & Present & Present & Present & Present & Present & Present & Present & Present & Present & Present \\
\hline Fibers & $\begin{array}{l}\text { Partially } \\
\text { septate }\end{array}$ & $\begin{array}{l}\text { Partially } \\
\text { septate } \\
2-3 \text { s/f }\end{array}$ & $\begin{array}{l}\text { Septate } \\
3 \mathrm{~s} / \mathrm{f}\end{array}$ & $\begin{array}{l}\text { Septate } \\
2-3 \mathrm{~s} / \mathrm{f}\end{array}$ & $\begin{array}{l}\text { Septate, } \\
2-4 \text { s/f }\end{array}$ & $\begin{array}{l}\text { Septate } \\
2-4 \mathrm{~s} / \mathrm{f}\end{array}$ & $\begin{array}{l}\text { Septate } \\
2 \mathrm{~s} / \mathrm{f}\end{array}$ & $\begin{array}{l}\text { Septate } \\
2-3 \mathrm{~s} / \mathrm{f}\end{array}$ & $\begin{array}{l}2-3 \\
\text { (3) } s / f\end{array}$ & $\begin{array}{l}\text { Partially septate } \\
2-3 \mathrm{~s} / \mathrm{f}\end{array}$ & $\begin{array}{l}\text { Septate } \\
2-3 \mathrm{~s} / \mathrm{f}\end{array}$ \\
\hline $\begin{array}{l}\text { Axial } \\
\text { parenchyma }\end{array}$ & Absent & Absent & $\begin{array}{l}\text { Scanty } \\
\text { paratracheal }\end{array}$ & Absent & Absent & $\begin{array}{l}\text { Scanty } \\
\text { paratracheal }\end{array}$ & Absent & $\begin{array}{l}\text { Scanty } \\
\text { paratracheal }\end{array}$ & Absent & Absent & Absent \\
\hline
\end{tabular}


the subtribe Flueggeinae of the Hymenocardieae and Antidesma that include the absence of axial parenchyma (sometimes very scarce in Flueggeinae and Antidesma), septate fibers (partially in Antidesma) and large oval and horizontally elongated vessel-ray pits often with a scalariform pattern.

Very similar anatomical characters are found in woods of Phyllanthus, Margaritaria, Flueggea (subtribe Flueggeinae) and Hymenocardia (Hymenocardieae) and Antidesma (Antidesmeae) (Table 3). These taxa are difficult to distinguish from one another based on their xylem structure alone. Phyllanthus has marked anatomical variations among its species, thus can show greater similarity with other members of the Flueggeinae, Hymenocardia or Antidesma. Although Paraphyllanthoxylon coloradensis does exhibit close anatomical similarity to Antidesma montanum based on the presence of septate and non-septate fibers, both new fossil Paraphyllanthoxylon morphotypes can be distinguished from Antidesma by the presence of relatively large vessel elements (Mennega, 1987) and predominantly biseriate rays in Antidesma (Table 3). Margaritaria (e.g. M. indica) can also be distinguished from the fossils, given that biseriate rays dominate [personal observations of NHN Utrecht slide (Uw 10905)] and Hymenocardia wallichii (Uw 14634) differs from the fossils in that it has 4 septa per fiber.

In summary, although the anatomical characters of the El Cien Paraphyllanthoxylon morphospecies also occur within the Flacourtiaceae, greatest anatomical similarity is shared with the Glochidion-group of the Phyllanthoideae, the Flueggeinae (of the Hymenocardieae) and Antidesma, all belonging to the Euphorbiaceae.

\section{Family: Leguminosae}

Genus: Andiroxylon Müller-Stoll and Mädel (1967) Species: Andiroxylon cinnamomeus sp. nov. Plate IV. Etymology: The specific epithet refers to the cinnamon colour of the samples.

Holotype: LPB 4115-4126 (18 cm).

Additional material: LPB 4218-4227 (ca. $11.5 \mathrm{~cm}$ ).

Repository: Paleontological Collection of the Instituto de Geología, UNAM, Mexico.

Stratigraphic horizon: Cerro Colorado Member of the El Cien Formation, early Miocene.

Locality: Cañada El Canelo, Mexico (Fig. 1).

Species diagnosis: Wood diffuse porous, indistinct growth rings; vessels mostly solitary and in radial pairs, sporadically in multiples of four; perforation plates simple, intervascular pits oval to polygonal; vessel-ray pits and vessel-parenchyma pits similar to intervascular pits; fibers non-septate; axial parenchyma aliform and confluent to banded; parenchyma strands (3-)4(-6) cells high; axial parenchyma and rays irregularly storied; rays heterocellular, predominantly multiseriate with rare uniseriates; multiseriate rays 2-4 cells wide, body composed of procumbent cells, $0-3$ marginal rows of square or weakly procumbent cells. Description: This description is based on two pieces of wood with estimated diameters of ca. 11.5 and $18 \mathrm{~cm}$. Diffuse porous wood with indistinct growth rings (Plate IV, 1-3). Vessels round to oval in outline, mostly solitary and in radial pairs, but sporadically form larger groups (up to 4), with vessel grouping index of 1.25. Vessel element tangential diameter varies from 120 to $225 \mu \mathrm{m}(x=158 \mu \mathrm{m}, s=25.4)$, length measures $185-400 \mu \mathrm{m}(x=335 \mu \mathrm{m}, s=48)$, wall-thickness varies from 4 to $12 \mu \mathrm{m}(x=7.3 \mu \mathrm{m}$, $s=1.9)$ and frequency varies from 0 to $6 \mathrm{~mm}^{-2}(x=2.8$ $\mathrm{mm}^{-2}, s=1.3$ ). Perforation plates simple with almost transverse end walls. Intervascular pits oval to polygonal (Plate IV, 10), 5-8 $\mu \mathrm{m}(x=6.2 \mu \mathrm{m}, s=1)$ in diameter. Vessel-ray and vessel-parenchyma pits similar to intervascular pits, sometimes alternate with no conspicuous border reduction (Plate IV, 11). Thinwalled tyloses present. Libriform non-septate fibers present with tangential diameters varying from 3 to 17 $\mu \mathrm{m}(x=9.2 \mu \mathrm{m}, s=3.1)$ and wall-thickness ranging between 2 and $7 \mu \mathrm{m}(x=4 \mu \mathrm{m}, s=1.2)$, some with very thick walls (Plate IV, 9). Axial parenchyma is aliform with either short or long wings, often confluent, frequently banded due to wing convergence (Plate IV, 1-3). In longitudinal section axial parenchyma strands mainly (3)-4-(6) cells high (Plate IV, 6, 7) and irregularly storied. Rays heterocellular, predominantly multiseriate but some uniseriate (Plate IV, 4, 5) and irregularly storied, frequency of $6-10$ per $\mathrm{mm}(x=8.5$ per $\mathrm{mm}, s=1.2)$. Multiseriate rays 2-3(4) cells wide and 190-345 $\mu \mathrm{m}(x=259 \mu \mathrm{m}, s=44)$ high. Body of multiseriate rays composed of exclusively procumbent cells with $0-3(x=1.2, s=0.6)$ rows of square or weakly procumbent cells forming uniseriate extensions (Plate IV, 8); uniseriate rays composed exclusively of procumbent cells.

Affinities: The characters shared by these fossils with members of the Leguminoseae are the storied nature of the axial and radial parenchyma, abundance of the axial parenchyma, similarity of the vessel-ray and vesselparenchyma pits to intervascular pits and presence of simple perforation plates.

Although the structure of the secondary xylem in legumes is extremely variable (Metcalfe and Chalk, 

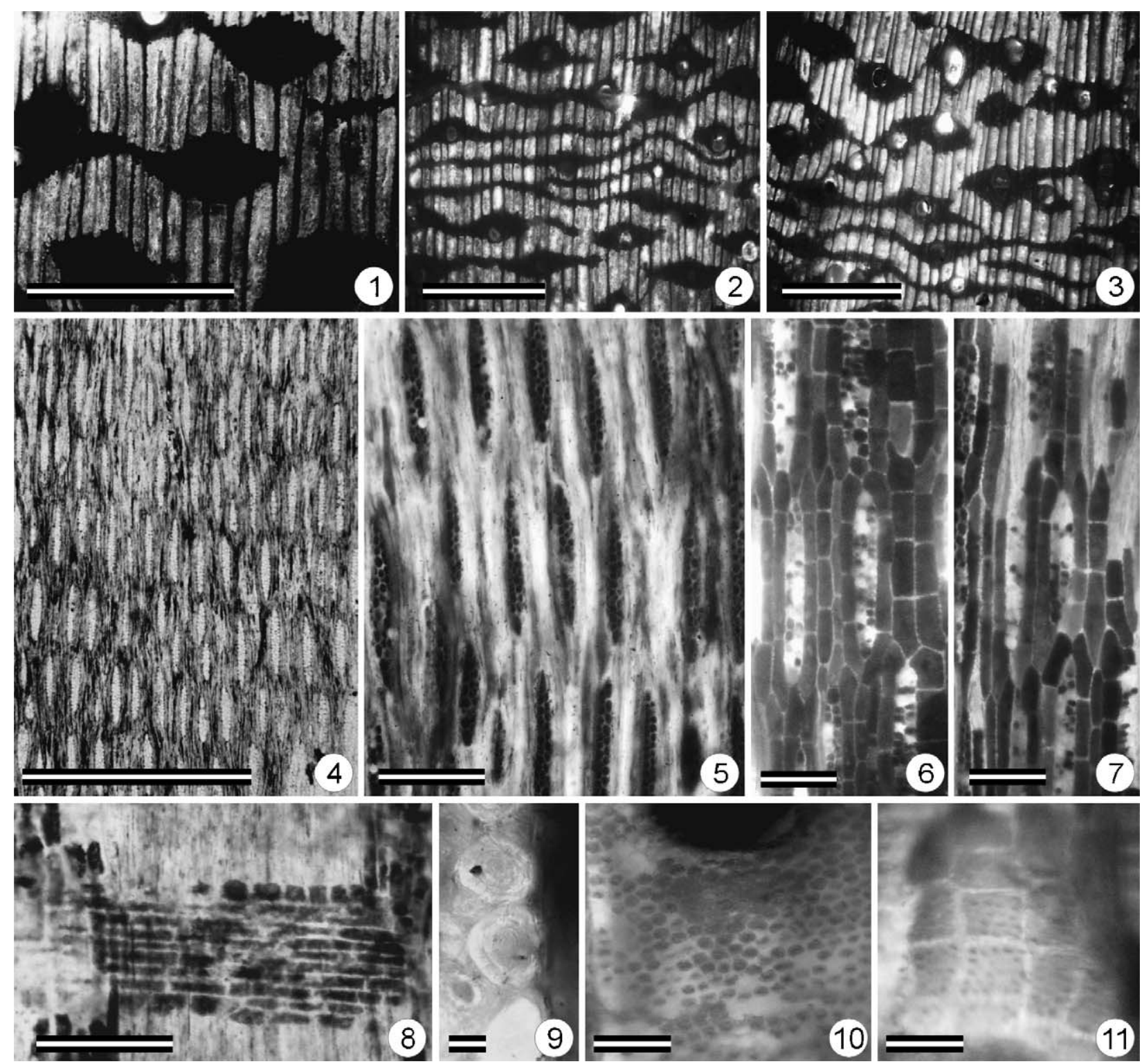

Plate IV. Light micrographs of Andiroxylon cinnamomeus.
$1,2,3$.
Ts. Variability of the axial parenchyma types. Aliform to confluent and banded. LPB-IGM 4120 . Scale bar=1 $\mathrm{mm}$.
4,5 . Tg. Storied and heterocellular rays. LPB-IGM 4116, 4221. Scale bar $=1 \mathrm{~mm}$ and $250 \mu \mathrm{m}$.
6,7 .
8.
9.
10.
11. Tg. 3-6 celled parenchyma strands, storied axial parenchyma. LPB-4117. Scale bar $=150 \mu \mathrm{m}$. Rs. Heterocellular ray, note the square and weakly procumbent marginal cells. LPB-4123. Scale bar $=150 \mu \mathrm{m}$. Ts. Very thick-walled fibers with virtually no lumen. LPB-4121. Scale bar $=15 \mu \mathrm{m}$. Rs. Alternate intervascular pitting. LPB-4222. Scale bar $=50 \mu \mathrm{m}$. Rs. Vessel-ray pits. LPB-4222. Scale bar $=50 \mu \mathrm{m}$.

1950; Baretta-Kuipers, 1981), the relative presence of certain characters has been valuable in the recognition of anatomical trends at the subfamily level. BarettaKuipers (1981) has documented the significance of ray- and axial parenchyma structure and cell composition in the taxonomy of the family. According to these trends, Mimosoideae may be distinguished from Papilionoideae and Caesalpinioideae in having shorter 
homocellular rays, lower proportion of axial parenchyma bands $>4$ cells wide, greater proportion of septate fibers and absence of storied structures. Conversely, the Papilionoideae differs from Caesalpinioideae in having species with greater occurrence of storied structure elements, smaller proportion of heterocellular rays, and relatively shorter rays (Baretta-Kuipers, 1981).

The anatomical pattern of the El Cien Formation wood is particularly similar to the wood anatomical characters displayed by members of the tribes Swartzieae and Dalbergieae (and Sophoreae) of the Papilionoideae. Within the tribe Swartzieae the fossil wood shares greatest similarity with Aldina, Cordyla and Mildbraediodendron excelsum, namely: (i) thick walled fibers (with virtually no lumen), (ii) abundance of axial parenchyma, (iii) regular/irregular storeying of axial and radial parenchyma, and (iv) height, width and cell composition of the rays. However, the number of cells that form the axial parenchyma strands in the fossil (i.e. 3-6 cells) differs from that in these genera: Aldina and Cordyla have strands of 2-4 cells (Gasson, 1996; Angyalossy-Alfonso and Miller, 2002) and M. excelsum has strands of 3-5 cells (Gasson, 1996; or 2-4 cells according to Angyalossy-Alfonso and Miller, 2002) (Table 4).

Within the Dalbergieae anatomical similarity is closest to a group of four genera whose wood anatomy is atypical within this tribe: Andira, Hymenolobium, Vatairea and Vataireopsis. Based on the virtual absence of uniseriate rays and the absence of strictly storied structure in all axial parenchyma and rays, this group is anatomically closer to members of the Sophoreae (Baretta-Kuipers, 1981; Gasson, 1996). Baretta-Kuipers
(1981) relates them directly with Ormosia. The fossils from the El Cien Formation differ from Hymenolobium, Vatairea and Vataireopsis in the number of cells per axial parenchyma strand $(2-4$ cells, sometimes $2-$ 8 cells high in Vatairea guinensis [Reinders-Gouwentak, 1955]) and in the absence of septate fibers (in the comparative material studied, septate fibers were observed only in Vatairea guinensis even though Gasson, 1999 indicates that they are present in all three genera).

The species of Andira that were available for comparative study can be subdivided in two groups based on wood characteristics (Table 4). Andira coriacea (Plate V, 4), A. inermis and A. villosa (Plate $\mathrm{V}, 5)$ are notably different from $A$. retusa and $A$. surinamensis (Plate V, 1-3, 6) in both the size of the multiseriate rays and the upper limit of cells per parenchyma strand. In $A$. coriacea most multiseriate rays are extremely high with only the shorter rays having a slight tendency towards a storied nature. Rays 5 cells wide (wider than in the fossil) are extremely common in A. villose and A. surinamensis (Table 4). These three species of Andira have 3-6 cells per axial parenchyma strand, commonly 4 cells, but up to 7 in $A$. villose. Rays of $A$. retusa and $A$. surinamensis do not exceed the 20 cells in height and 4 cells in width, and axial parenchyma strands are shorter (Table 4). Although the combination of anatomical features in the new fossil legume morphotype from the El Cien Formation does vary slightly from those observed in the extant species of Andira, the number of cells in the axial parenchyma strands in the fossil is closer to $A$. coriacea, $A$. inermis and $A$. villose, while the size of the rays (height and width) is similar to that of $A$. retusa and $A$.

Table 4

Anatomical comparison of selected Andira species and Andiroxylon cinnamomeus. Bold type denotes the most frequently encountered condition; * highest number of ray cells; [ ] extreme values; - absent;,,++++++ axial parenchyma abundance (relatively few to relatively abundant)

\begin{tabular}{|c|c|c|c|c|c|c|}
\hline Character & $\begin{array}{l}\text { Andira coriacea } \\
\text { Uw } 11500\end{array}$ & $\begin{array}{l}\text { Andira inermis } \\
\text { Uw } 7077\end{array}$ & $\begin{array}{l}\text { Andira retusa } \\
\text { Uw } 9129\end{array}$ & $\begin{array}{l}\text { Andira surinamensis } \\
\text { Uw 57, } 14476\end{array}$ & $\begin{array}{l}\text { Andira villose } \\
\text { Uw } 1384\end{array}$ & $\begin{array}{l}\text { Andiroxylon } \\
\text { cinnamomeus }\end{array}$ \\
\hline $\begin{array}{l}\text { Vessel diameter } \\
\qquad(\mu \mathrm{m})\end{array}$ & 259 & 230 & 196 & 229 & 224 & 157 \\
\hline $\begin{array}{l}\text { Vessel frequency } \\
\qquad\left(\mathrm{v} / \mathrm{mm}^{2}\right)\end{array}$ & 1.7 & 2.7 & 1.8 & 1.8 & 2.1 & 2.8 \\
\hline $\begin{array}{l}\text { Ray frequency } \\
\qquad(\mathrm{mm})\end{array}$ & 4.3 & 5.5 & 8 & 5 & 4.9 & 8.5 \\
\hline Ray height $(\mu \mathrm{m})$ & 615 & 334 & 293 & 367 & 394 & 259 \\
\hline Ray height (cells)* & 50 & 21 & 18 & 17 & 27 & 18 \\
\hline Ray width (cells) & $2-4,3-4$ & $2-5,3-4$ & $2-4, \mathbf{2}-\mathbf{3}$ & $2-4,2-3$ & $2-5,3-4$ & $2-4,2-3$ \\
\hline Strands (cells) & (3) $4-6$ & (3) $4-6[4]$ & $3-4(5)[4]$ & $3-4[4]$ & $3-6-(7)[4]$ & (3) $4-6[4]$ \\
\hline \multicolumn{7}{|l|}{ Axial parenchyma } \\
\hline Aliform & +++ & - & +++ & + & ++ & +++ \\
\hline Confluent & + & +++ & +++ & +++ & +++ & ++ \\
\hline Banded & - & +++ & + & +++ & ++ & + \\
\hline
\end{tabular}



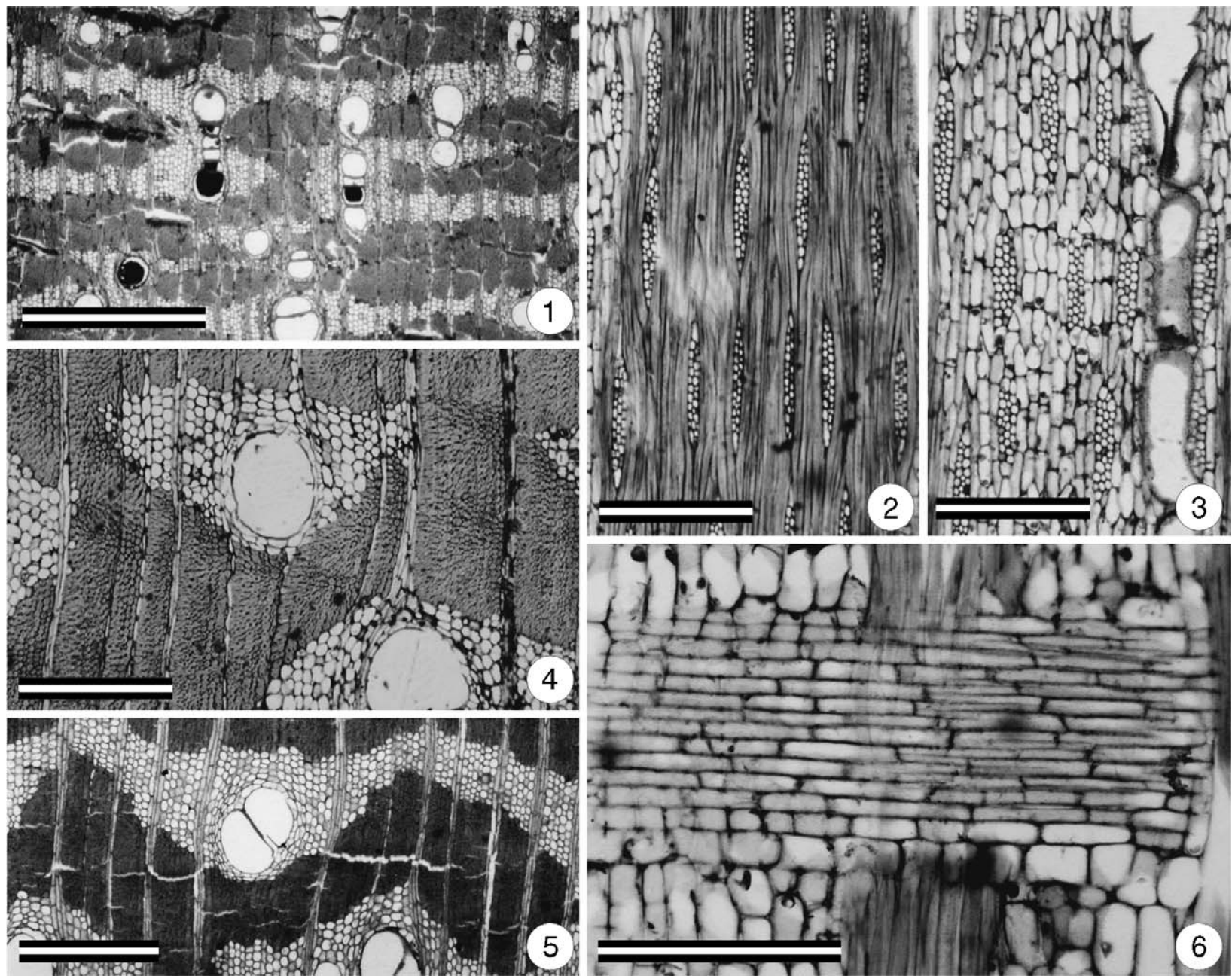

Plate V. Light micrographs of Andira. Andira surinamensis Uw. 14476 (Figs. 1-3, 6), Andira coriacea Uw 11500 (Fig. 4), Andira villosa Uw 1384 (Fig. 5).

1, 4, 5. Ts. Axial parenchyma types in different species of Andira. Scale bar= 1 mm (Fig. 1), $500 \mu \mathrm{m}$ (Figs. 4 and 5)

2. Tg. Storied rays. Scale bar $=500 \mu \mathrm{m}$.

3. Tg. Storied rays and axial parenchyma. 4-6 celled parenchyma strands. Scale bar $=500 \mu \mathrm{m}$.

6. Rs. Heterocellular ray with one row of weakly procumbent cells. LPB-4117. Scale bar $=250 \mu \mathrm{m}$.

surinamensis (Table 4). Overall the fossil is most similar to $A$. retusa, with which it shares comparable quantitative and qualitative vessel, ray, and axial parenchyma features. The only difference lies in the length of the axial parenchyma strands. Thus, we consider this fossil morphotype exhibits anatomy closest to that of extant Andira and have therefore placed it in the fossil genus Andiroxylon erected for fossil woods with anatomical similarity to extant Andira (Müller-Stoll and Mädel, 1967).

In the fossil record only one species has been described with anatomical similarity to extant Andira, namely the type species, $A$. biseriatum Müller-Stoll and
Mädel (1967), from Kenya. The major distinction between the El Cien woods and $A$. biseriatum includes the number of cells per parenchyma strand, the absence of crystals and the parenchyma distribution. Although rays of $A$. biseriatum were defined by Müller-Stoll and Mädel (1967) as being homocellular, they described them as having "marginal cells only a little bit higher than cells of the body", therefore they are equivalent to the weakly procumbent cells seen in the El Cien wood. The number of cells per parenchyma strand in the El Cien woods (3-6 cells) is closer to the extant species studied [i.e. 3-6(-7); Table 4] than to A. biseriatum (48 ). Additionally, the presence of crystals in the axial 
parenchyma and the relative abundance of axial parenchyma in $A$. biseriatum distinguish this species from the El Cien woods. Therefore, the erection of a new species, $A$. cinnamomeous, for the El Cien woods is justified.

\section{Family: Moraceae}

Genus: Ficoxylon Kaiser (1880).

Species: Ficoxylon bajacaliforniense sp. nov. Plate VI, 1-9; Plate VII, 1, 2.

Etymology: The specific epithet indicates the Mexican State in which the fossil samples were collected.

Holotype: LPB-IGM 1205-1210 (ca. $17.3 \mathrm{~cm}$ ).

Additional material: LPB-IGM 1236-1239 (5.8 cm); LPB-IGM 3557-3560 (14.2 cm); LPB-IGM 42764291(ca. $12.5 \mathrm{~cm}$ ); LPB-IGM 5475-5476 (ca. $8 \mathrm{~cm}$ ).

Repository: Paleontological Collection of the Instituto de Geología, UNAM, Mexico.

Stratigraphic horizon: Cerro Colorado Member of the El Cien Formation, early Miocene.

Locality: Rancho Matanzas (LPB-IGM 1205-1210; LPB-IGM 1236-1239) and Cañada El Canelo (LPBIGM 3557-3560; LPB-IGM 4276-4291; LPB-IGM 5475-5476), Mexico (Fig. 1).

Species diagnosis: Wood diffuse porous, growth rings indistinct; vessels mainly solitary and in radial multiples of 2-3 (4), average diameter of ca. $150 \mu \mathrm{m}$ and mean frequency of ca. 3 per $\mathrm{mm}^{-2}$; perforation plates simple, intervascular pits alternate, oval to polygonal; vessel-ray and vessel-parenchyma pits larger than intervascular pits, round to oval with reduced borders; libriform fibers non-septate; axial parenchyma paratracheal vasicentric, concentric apotracheal bands, and 4-6 cells in height; up to 13 rhombic crystals in chambered parenchyma cells; rays homocellular, mostly multiseriate, $2-8$ cells wide; some sheath cells present.

Description: This description is based on five pieces of wood with estimated diameters ca. 6 to $>17 \mathrm{~cm}$. Diffuse porous wood with indistinct growth rings; vessel round to oval in cross section, solitary, and in radial multiples of 2-3 (4) with vessel grouping index of 1.7 (Plate VI, 1, 2). Vessel element tangential diameter ranges from 90 to $215 \mu \mathrm{m}(x=154 \mu \mathrm{m}, s=33)$, length measures 195-375 $\mu \mathrm{m}(x=290 \mu \mathrm{m}, s=61)$, wall thickness measures 6-15 $\mu \mathrm{m}(x=9.7 \mu \mathrm{m}, s=2.6)$ and frequency varies from 0 to 6 $\mathrm{mm}^{-2}\left(x=3 \mathrm{~mm}^{-2}, s=1.8\right)$. Perforation plates simple with almost transverse end walls (Plate VI, 9). Intervascular pits alternate, oval to polygonal (Plate VI, 3), and 3-7 $\mu \mathrm{m}(x=5 \mu \mathrm{m}, s=1.2)$ in diameter. Vessel-ray and vessel-parenchyma pits round to oval with reduced borders and larger than intervascular pits
(Plate VII, 1, 2). Thin-walled tyloses. Non-septate libriform fibers form the ground tissue, with tangential diameter measuring $1-8 \mu \mathrm{m}(x=4 \mu \mathrm{m}, s=1.7)$ and wallthickness of 3-9 $\mu \mathrm{m}(x=5.4 \mu \mathrm{m}, s=1.3)$. Axial parenchyma apotracheal in concentric bands of 5-12 cells wide and $2-3$ per $\mathrm{mm}$, and paratracheal vasicentric (Plate VI, 1, 2). In longitudinal section axial parenchyma strands up to 4-6 cells in height (Plate VI, 8). Crystalliferous strands up to 15 crystals, one per chamber in axial parenchyma (Plate VI, 6, 7). Rays homocellular (Plate VI, 4, 5, 8), mainly multiseriate with frequency of $4-8$ per $\mathrm{mm}(x=5.8$ per $\mathrm{mm}, s=1.2)$. Multiseriate rays 2-6 (-8) cells wide and $130-1110 \mu \mathrm{m}$ $(x=632, s=293 \mu \mathrm{m})$ high, composed predominantly of procumbent cells although some have slightly squarer cells. Some sheath cells present. The uniseriate extensions of multiseriate rays composed of $1-7(x=2, s=1)$ rows of procumbent cells. Uniseriate rays represent less than $10 \%$ of ray tissue and are $5-15(x=8.3, s=3.4)$ cells high.

Affinities: Ficus is the largest genus of the Moraceae with more than 900 species in Africa, America and Australasia, and although it grows in a wide diversity of habitats (from humid forest to relatively dry zones) and exhibits a variety of habits, its wood anatomy is remarkably homogeneous (Koek-Noorman et al., 1984). Ficus can be distinguished from the other members of the Moraceae by the presence of few, relatively large vessels, long apotracheal bands, 3-15 cells wide (Plate VI, 10), non-septate libriform fibers (sporadically some septate) and the rhomboidal crystals in marginal ray cells and axial parenchyma (Koek-Noorman et al., 1984). The conspicuous parenchyma bands that in some cases make up 50\% of the axial tissue are rarely found in other Moraceae genera (Koek-Noorman et al., 1984). The other Moraceae genera with relatively large amounts of axial parenchyma and homocellular rays are Clarsia, Parartocarpus and Morus. However, they can be differentiated by the number of cells per parenchyma strand: Morus and Clarisia have 2-4 cells per strand (ter Welle et al., 1986a,b), whereas Parartocarpus has 3-4 cells per strand (ter Welle et al., 1986b). Both the El Cien woods and the extant species of Ficus have longer parenchyma strands, i.e. 4-6 cells and 4-6 [10] cells (Koek-Noorman et al., 1984), respectively. The fossil woods of the El Cien Formation is both quantitatively and qualitatively very similar to the extant species of Ficus (Plate VI, 10-12) with only slight deviations in fiber lumen and wall thickness and in the number of cells in the uniseriate extensions of the multseriate rays. 
Several fossil woods have been assigned to Ficoxylon, a fossil organ genus erected by Kaiser (1880) for woods with anatomical similarity to extant Ficus. The majority of the fossil woods assigned to this genus originate from northern Africa (e.g. Schenk, 1883; Kamal El-Din, 2003), but it has been also found in Colombia (Boureau and Salard, 1962). Anatomical differences between the wood from the El Cien Formation and those Ficus assigned to other species can be noted. The species with greatest anatomical similarity to the El Cien plant is $F$. cretaceum from the Cretaceous of northern Africa. It has relatively greater abundance of uniseriate rays, narrower (up to three cells wide; Schenk, 1883; Boureau and Salard, 1962; Kamal
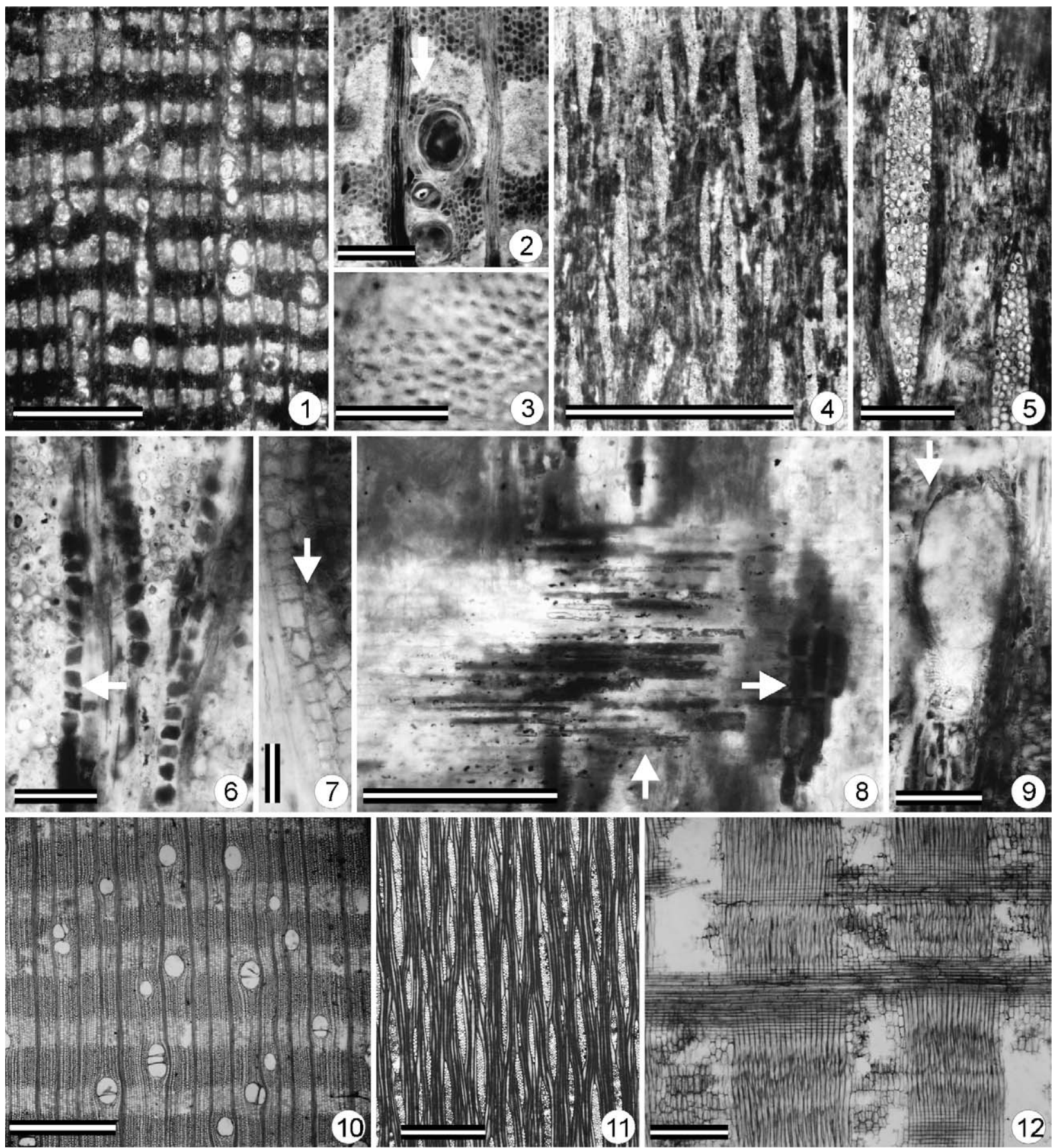

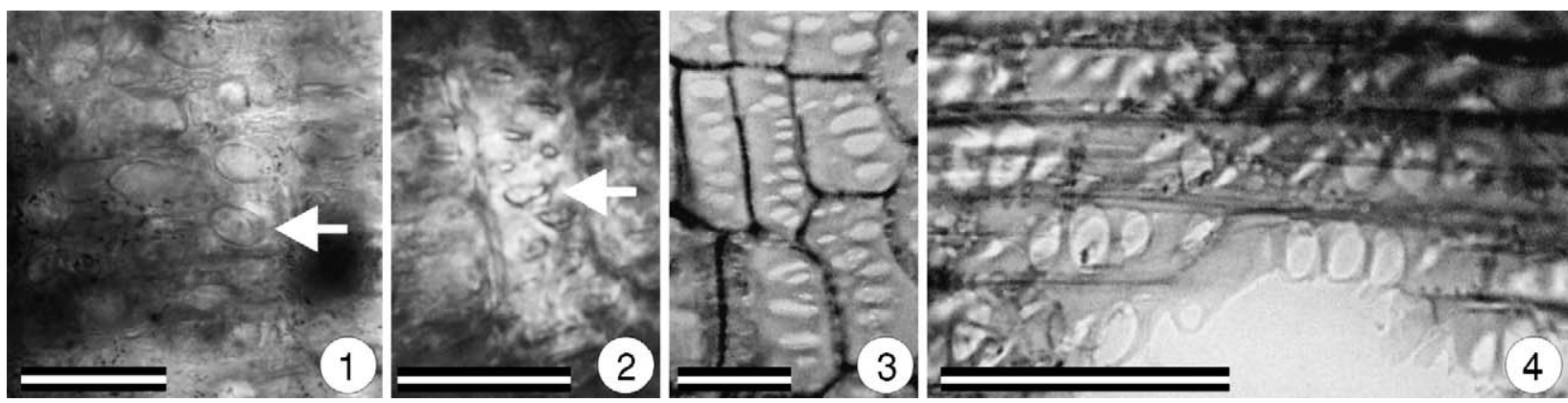

Plate VII. Light micrographs of Ficoxylon bajacaliforniense LPB-IMG 4287 (Figs. 1 and 2), Ficus glauscens MEXU-139 (Fig. 3) and F. goldmanii MEXU-486 (Fig. 4)

1, 2. Rs. Vessel-ray and vessel-parenchyma pits (arrowed) respectively. Scale bar $=50 \mu \mathrm{m}$.

3, 4. Rs. Vessel parenchyma and vessel-ray pits respectively. Scale bar $=50 \mu \mathrm{m}$.

El-Din, 2003) multiseriate rays and sometimes nonseptate fibers (see Schenk, 1883; Kamal El-Din, 2003 for further details), thus we believe that there is sufficient anatomical distinction to warrant the erection of a new species for the Ficus-like woods from the El Cien Formation.

\section{Discussion}

The El Cien Formation has yielded a wellpreserved fossil wood flora. In total 23 plant types have been recorded but only five have been in previous works. These taxa include several legumes (Mimosoxylon tenax [Felix] Müller-Stoll and Mädel, 1967, Bajacalifornioxylon cienense, Copaiferoxylon matanzensis Cevallos-Ferriz and Barajas-Morales, 1994), one moraceous wood (Maclura; MartínezCabrera, 2002) and an anacardiaceous plant (Tapirira peninsularis; Martínez-Cabrera and Cevallos-Ferriz, 2004). Other five are described here. A high percentage of near living relatives of the plants identified from the El
Cien Formation assemblage are found today in the deciduous tropical forests on the western coast of Mexico. Greatest forest composition similarity is found in the biological station of Chamela (UNAM), located in the state of Jalisco. Based on the material so far identified in El Cien localities, Leguminosae is the most diverse taxonomic group in terms of number of species, followed closely by Euphorbiaceae along with Moraceae. Significantly, the Leguminosae and Euphorbiaceae are also the most diverse families in Chamela (Lott, 1985; Lott and Atkinson, 2002). Although there may be doubts concerning the inclusion of the Paraphyllanthoxylon species within the Euphorbiaceae. This brings the total of taxa described from the El Cien Formation and shared with those from Chamela to seven, with one of the most diverse genera at Chamela, Mimosa, also present in the fossil flora (Table 5).

The extant relatives of the El Cien Formation plants present in Chamela represent both deciduous taxa, restricted to the deciduous tropical forest (e.g. Maclura; Lott, 2002), and evergreen trees mainly distributed in

Plate VI. Light micrographs of Ficoxylon bajacaliforniense (Figs. 1-9) and Ficoxylon yoponensis MEXU 128 (Figs. 10-12)

1,2. Ts. Diffuse porous wood with indistinct growth rings. Note the broad apotracheal axial parenchyma bands and paratracheal vasicentric. LPB-IGM 1205. Scale bar $=1 \mathrm{~mm}$ and $200 \mu \mathrm{m}$.

3. Tg. Alternate intervascular pitting. LPB-IGM 3557. Scale bar $=50 \mu \mathrm{m}$.

4. Tg. General view or the radial tissue; $1-6$ seriate rays. LPB-IGM 3557. Scale bar $=1 \mathrm{~mm}$.

5. Tg. Detail of a wide ray. LPB-IGM 3557. Scale bar $=200 \mu \mathrm{m}$.

6, 7. Tg. Crystalliferous strand in the axial parenchyma cells, note the rhombic shape of the crystals (arrowed). LPB-IGM 3557. Scale bar $=100$ and $50 \mu \mathrm{m}$.

8. Rs. Homogeneous radial tissue (vertical arrow); axial parenchyma strands (horizontal arrow). LPB-IGM 4288 . Scale bar=200 $\mu \mathrm{m}$.

9. Tg. Simple perforation plate (arrowed). LPB-IGM 3557. Scale bar $=150 \mu \mathrm{m}$.

10. Ts. Diffuse porous wood; apotracheal parenchyma bands. Scale bar $=1 \mathrm{~mm}$.

11. Tg. General view of the rays. Scale bar $=500 \mu \mathrm{m}$.

12. Homocellular rays. Scale bar $=500 \mu \mathrm{m}$. 
Table 5

Habitat preference, habit and phenology of the nearest living relatives of the fossil woods from the El Cien Formation

\begin{tabular}{|c|c|c|c|c|}
\hline Fossil genus & Living relative & Phenology & Habit & Habitat \\
\hline Andiroxylon & Andira $^{\mathrm{a}}$ & Evergreen & $\mathrm{t}, \mathrm{s}(10-35 \mathrm{~m})+$ & TSDF+, TRF \\
\hline Copaiferoxylon & Copaifera & Evergreen & $\mathrm{t}(15-35 \mathrm{~m})$ & DF, TRF \\
\hline Ficoxylon & Ficus $^{\mathrm{a}}$ & E, D & $\mathrm{t}$, hem $(8-18 \mathrm{~m})+$ & $\mathrm{Ri}+, \mathrm{TDF}+, \mathrm{TSDF}+$ \\
\hline Maclura & Maclura $^{\mathrm{a}}$ & Deciduous & $\mathrm{t}(6-20 \mathrm{~m})+$ & TDF+ \\
\hline Mimosoxylon & $\operatorname{Mimosa}^{\mathrm{a}}$ & Deciduous & $1, . \mathrm{c}, \mathrm{s}, \mathrm{t}(1,4-8)+$ & $\mathrm{Ri}+$, TDF,+ TSDF + \\
\hline $\begin{array}{l}\text { Paraphyllanthoxylon } \\
\text { mennegae }\end{array}$ & Phyllanthus ${ }^{\mathrm{a}}$ & Deciduous & $\mathrm{t}, \mathrm{s}, \mathrm{h}(1-12 \mathrm{~m})+$ & $\mathrm{TDF}+, \mathrm{Hal}+, \mathrm{Ri}+$ \\
\hline P. coloradensis & Phyllantoidae $^{-}$ & - & - & - \\
\hline Tapirira & Tapirira & Evergreen & $\mathrm{t}$ (up to $40 \mathrm{~m}$ ) & TRF, MF \\
\hline Tetragastroxylon & Tetragastris & Evergreen & $\mathrm{t}(20-30 \mathrm{~m})$ & TRf \\
\hline
\end{tabular}

${ }^{a}$ Nearest living relatives present at Chamela; in the habit column + represents the height and habit of the nearest living relatives present at Chamela; the habitat column provides the vegetation type of the nearest relative at Chamela; E, evergreen; D, deciduous;-, taxonomic relationship uncertain; $t$, trees; s, shrubs; hem, hemiepiphyte, h, herb; c, woody climbers; 1, lianas. TDF, tropical deciduous forest; TRF, tropical rain forest; DF, dry forest; Ri, riparian; Hal, halophyte; MF, mountain forest (data from Chamela after Lott, 2002).

the sub-deciduous tropical forest (e.g. Andira; Lott, 2002) (Table 5). In addition there are other taxa in the fossil assemblage that can be found in either both of these vegetation types and/or in riparian environments (e.g. Ficus, Mimosa; Lott, 2002) (Table 5). Moreover, the fossil assemblage contains other taxa whose closer living relatives, Tapirira, Copaifera and Tetragastris (or Protium), do not occur at this latitude along the Pacific coast today, but are restricted to more humid areas to the south. Tapirira lives in more humid environments at mid-elevations either in the mountain forests ( $T$. mexicana) or rain forest (T. chimalapana), essentially in southeastern Mexico and Central and South America (Terrazas and Wendt, 1995). Copaifera, native of South America and Africa, grows in dry and humid tropical and sub-tropical areas with precipitation and temperature tolerance ranges from 1000 to $4000 \mathrm{~mm} / \mathrm{yr}$ and 20 to $27{ }^{\circ} \mathrm{C}$, respectively. Nevertheless, the majority of the Copaiferas occurs in areas with $3500 \mathrm{~mm}$ or more of precipitation and ca. $27{ }^{\circ} \mathrm{C}$ of MAT (http://www.hort. purdue.edu, 2003). Tetragastris is distributed in humid or gallery forests of South America (http://scisun.nybg. org, 2003; http://ctrs.si.edu, 2003) and southern Mexico (Martínez, 1987). Evidently, the moisture requirements of the latter three extant taxa are greater than the other nearest living relatives of other fossil taxa found in the El Cien Formation. Assuming that the ecological tolerances of these taxa have not changed appreciably over the last 20-25 my, the El Cien flora may have grown in an environment characterised by higher humidity compared with the current conditions in Chamela and the Baja California Peninsula. The tolerances of Andira, Ficus and Mimosa may overlap with those of Tetragastris, Tapirira and Copaifera, but other taxa such as Maclura tinctoria grow in Chamela at relatively higher water stress levels (Lott, 2002); even though, M. tinctoria can thrive in more humid forests (tropical rain forest) as demonstrated by its presence in Manaus (Brazil), where a mean annual precipitation of $2275 \mathrm{~mm}$ prevails.

The extant vegetation of Chamela is dominated by deciduous tropical forest, although sub-deciduous forest associated with wide valleys with rivers is also present in the natural reserve (Durán et al., 2002). Based on the above preliminary comparison we suggest that the landscape at the time of deposition of the El Cien Formation, was composed of a mixture of evergreen and deciduous plants, similar to those growing in Chamela, but with some additional taxa that grow today under more humid conditions in different vegetation types (Table 5).

In order to more fully determine the palaeoecology of the El Cien Formation, the wood of its 23 distinct plant types was subject to statistical analyses (Martínez Cabrera, 2004). The results strongly support the presence of a moist/humid tropical environment in this region during the early Miocene (25-20 my), supporting plants with a deciduous or semi-deciduous habit (Martínez Cabrera, 2004).

By about 3.5 my the Baja California region was cut off from the North American Plate and subsequently became incorporated onto the Pacific Plate (Hausback, 1984). Therefore, since these geographic areas share a common history the floristic similarity between the El Cien Formation and the western coast Mexico is not surprising. However, the displacement of the Baja California Peninsula following its severance with the North American Plate, resulted in the Peninsula becoming much drier. Today, in the vicinity of the El Cien Formation outcrop the characteristic vegetation is a xeric thicket, but to the east of the outcrops, restricted to 
a thin strip in the lower eastern third of Southern Baja California, dry tropical forest (drier than Chamela) still prevails (Rzedowski, 1978).

This work adds new information to the biodiversity of Baja California Sur, Mexico, 25-20 my ago. Moreover, the evidence presented here supports the hypothesis of the existence of a relatively humid tropical climate during the early Miocene that became progressively drier during the later Miocene and into the Pliocene. This had major implications for the vegetation in this region. With more studies focusing on both the woods from the El Cien Formation and floras from younger deposits, the picture of environmental change in this area of Mexico over the last $\sim 25$ my can be further developed and the evolution of the Mexican flora more fully understood.

\section{Acknowledgements}

We would like to acknowledge to Dr. A.M.W. Mennega and Dr. J. Koek-Noorman for their helpful comments on the wood anatomy of Euphorbiaceae and Moraceae, respectively. We also thank Dr. E.A. Wheeler and an anonymous reviewer for their comments on a previous version of the manuscript. Enoch Ortiz, Roberto Cabrera, Carlos Castañeda, Emilio Estrada (IGUNAM) and Dew Makhan (NHN, Utrecht) are acknowledged for their help in sectioning the fossil woods and extant material for anatomical comparison. Josefina Barajas-Morales and Paul Maas are thanked for allowing access to the slide collections at MEXU and NHN (Utrecht), respectively. H.I.M.C. thanks the Posgrado en Ciencias Biológicas and Instituto de Geología, UNAM, for providing funds to visit the NHN, University of Utrecht Branch. Comments by Mrs. Magdalena Alcayde, Editorial Department, Instituto de Geología, UNAM, improved a preliminary English version. This study is based in part on the Master thesis of H.I.M.C. at Posgrado en Ciencias Biológicas, UNAM. Funds by CONACyT (1005PT) and DGAPAUNAM (IN208500 and IN201103) through grants to S. R.S.C.F. and a CONACyT student loan 167130 to H.I. M.C are appreciated.

\section{References}

Alatorre, A.E., 1988. Stratigraphy and depositional environments of the phosphorite-bearing Monterrey Formation in Baja California Sur. Econ. Geol. 83, 1918-1930.

Angyalossy-Alfonso, V., Miller, R.B., 2002. Wood anatomy of the Brazilian species of Swartzia and considerations within the tribe Swartzieae. IAWA J. 23, 359-390.
Applegate, S.P., 1986. The El Cien Formation, strata of Oligocene and early Miocene age in Baja California Sur. Revista del Instituto de Geología de la Universidad Nacional Autónoma de Mexico 6, 145-162.

Atwater, T., 1970. Implications of plate tectonics for the Cenozoic tectonic evolution of western North America. Geol. Soc. Amer. Bull. 81, 125-132.

Awasthi, N., Mehrotra, R.C., 1993. Further contribution to Neogene flora of northeast India and significance of the occurrence of African element. Geophytology 23, 81-92.

Awasthi, N., Srivastava, R., 1989. Canarium Palaeoluzonicum, a new fossil wood from the Neogene of Kerala with remarks on the nomenclature of fossil woods of Burseraceae. The Palaeobotanist 37 (2), 173-179.

Bailey, I.W., 1924. The problem of identifying the wood of Cretaceous and later dicotyledons: Paraphyllanthoxylon arizonense. Ann. Bot. 38, 439-451.

Bande, M.B., Prakash, U., 1983. Fossil dicotyledonous woods from Deccan Intertrappean beds near Shahpura, Mandla District, Madhya Pradesh. The Paleobotanist 31, 13-29.

Baretta-Kuipers, T., 1981. Wood anatomy of Leguminosae: its relevance to Taxonomy. In: Polhill, R.M., Raven, P.H. (Eds.), Advances in Legume Systematics: Part 2. Royal Botanic Gardens, Kew, pp. 667-705.

Beal, C., 1948. Reconnaissance of geology and oil possibilities of Baja California, Mexico. Geol. Soc. Amer. Bull. 31, 1-138.

Boureau, E., Salard, M., 1962. Sur un bois fossile du Départament de Bolívar (Colombie). Boletin de Geología, Universidad Industrial de Santander 11, 35-44.

Cahoon, E.J., 1972. Paraphyllanthoxylon alabamense-a new species of fossil dicotyledonous wood. Am. J. Bot. 59 (1), 5-11.

Calvillo-Canadell, L., Cevallos-Ferriz, S.R.S., 2002. Bauhcis moranii gen. et sp. nov. (Cercideae Caesalpinieae) an Oligocene plant from Tepexi de Rodríguez, Puebla, Mexico with leaf architecture similar to Bauhinia and Cercis. Rev. Palaeobot. Palynol. 122, 171-184.

Cevallos-Ferriz, S.R.S., Barajas-Morales, J., 1994. Fossil woods from the El Cien Formation in Baja California Sur: leguminosae. IAWA Bull. n.s. 15, 229-245.

Cevallos-Ferriz, S.R.S., Ramírez-Garduño, J.L., 1998. Las plantas con flor en el registro fósil. Ciencias 52, 46-57.

Cevallos-Ferriz, S.R.S., Ricalde-Moreno, O.S., 1995. Palmeras fósiles del norte de México. Anales del Instituto de Biología, Universidad Nacional Autónoma de México, Serie Botánica 66, 37-106.

Cevallos-Ferriz, S.R.S., Weber, R., 1992. Dicotyledonous wood from the Upper Cretaceous (Maastrichtian) of Coahuila. Rev. Inst. Geol. UNAM. 10, 65-70.

Darton, N.H., 1921. Geologic reconnaissance in Baja California. J. Geol. 29, 720-748.

Dayal, R., 1964. Occurrence of Boswellia in the Deccan Intertrappean beds of Keria, Madhya Pradesh. Curr. Sci. 33, 683-684.

Den Bergen, L.G., 1923. Fossiele Houtsoorten uit het Tertiair von Zuid Sumatra. Verb. Geol. Mijnb. Genoot Ned. 7, 143-148.

Détienne, P., Jacquet, P., 1983. Atlas d'identification des bois de l'Amazonie et des régions voisines. Centre Technique Forestier Tropical.

Durán, E., Balvanera, P., Lott, E., Segura, G., Pérez-Jiménez, A., Islas, A., Franco, M., 2002. Estructura, Composición y dinámica de la vegetación. In: Noguera, F.N., Vega Rivera, J.H., García Alderete, A.N., Quesada Avendaño, M. (Eds.), Historia Natural de Chamela. 
Inst. Biol., Universidad Nacional Autónoma de Mexico, Mexico, pp. 443-472.

Estrada-Ruiz, E., 2004. Frutos permineralizados de la Formación Cerro del Pueblo (Maastrichtiano), Coahuila, México. MSc Thesis, Universidad Nacional Autónoma de México, México.

Fischer, R., Glli-Olivier, C., Gidde, A., Schwennicke, T., 1995. The El Cien Formation of southern Baja California, Mexico: stratigraphic precisions. Newsl. Stratigr. 32, 137-161.

Gasson, P., 1996. Wood anatomy of the tribe Swartzieae with comments on related Papilionoid and Caeasalpinoid Legume. IAWA J. n.s. 17, 45-75.

Gasson, P., 1999. Wood anatomy of the tribe Dipteygeae with comments on related Papilionoid and Caesalpinioid Leguminosae. IAWA J. n.s. 20, 441-455.

Ghosh, P.K., Roy, S.K., 1978. Fossil woods of Canarium from the Tertiary of west Bengala, India. Curr. Sci. 47, 804-805.

Gidde, A., 1992. Sedimentology of the Miocene Cerro Colorado Member (upper part of the El Cien Formation in Baja California Sur, Mexico). Zbl. Geol. Paläont. Teil. 1991, 1467-1477.

Haas, H., Rowe, N.P., 1999. Thin sections and wafering. In: Jones, T. P., Rowe, N.P. (Eds.), Fossil Plants and Spores: Modern Techniques. Geological Society, London, pp. 76-81.

Hausback, P.B., 1984. Cenozoic volcanic and tectonic evolution of Baja California Sur, Mexico. In: Frizze, V. (Ed.), Geology of the Baja California Peninsula. The Pacific Section Society of Economic Paleontologists and Mineralogists, Los Angeles California, pp. 219-237.

Heim, A., 1922. Notes on the Tertiary of southern lower California. Geol. Mag. 59, 529-547.

Herendeen, P.S., 1991. Lauraceous wood from the mid-Cretaceous Potomac group of eastern North America: Paraphyllanthoxylon marylandense sp. nov. Rev. Palaeobot. Palynol. 69, 277-290.

Hernández-Castillo, G., Cevallos-Ferriz, S.R.S., 1998. A plant permineralized with Haloragaceae affinity from the Upper Cretaceous of Sonora, Mexico. Am. J. Bot. (Abstract) 84, 134.

IAWA Committee, 1989. List of microscopic features for hardwood identification. IAWA Bull. n.s. 10, 219-329.

Ilic, J., 1987. The CSIRO Family Key for Hardwood Identification. EJ Brill, Leiden.

Ilic, J., 1991. CSIRO Atlas of Hardwoods. Springer-Verlag.

Kaiser, P.E.E., 1880. Ficoxylon bohemicum, ein neues fossiles Laubholz. Zeitschr. Gesamt. Naturw. 53, 309-317.

Kamal El-Din, M.M., 2003. Petrified wood from the Farafra Oasis, Egypt. IAWA J. n.s. 24, 163-172.

Kim, W.H., Barron, J.A., 1986. Diatom biostratigraphy of the upper Oligocene to lowermost Miocene San Gregorio Formation, Baja Clifornia Sur, Mexico. Diatom Res. 1, 169-187.

Koek-Noorman, J., Topper, S.M.C., ter Welle, B.J.H., 1984. The systematic wood anatomy of Moraceae (Urticales): III. Tribe Ficeae. IAWA Bull. n.s. 5, 330-334.

Lakhanpal, R.N., Prakash, U., Awasthi, N., 1981. Some more dicotyledonous woods from the Tertiary of Deomali, Arunachal Pradesh, India. The Palaeobotanist 27, 232-252.

LaPasha, C.A., Wheeler, E.A., 1987. A microcomputer based system for computer-aided wood identification. IAWA Bull. 8, 347-354

Lott, E.J., 1985. Listados florísticos de México III. La Estación de Biologíde Chamela, Jalisco. Herbario Nacional. Ins. Biol., Universidad Nacional Autónoma de Mexico, Mexico.

Lott, E.J., 2002. Lista anotada de las plantas vasculares de ChamelaCuixmala. In: Noguera, F.N., Vega Rivera, J.H., García Alderete, A.N., Quesada Avendaño, M. (Eds.), Historia Natural de Chamela.
Inst. Biol., Universidad Nacional Autónoma de Mexico, Mexico, pp. $99-136$.

Lott, E.J., Atkinson, T.H., 2002. Biodiversidad y fitogeografía de Chamela-Cuixmala, Jalisco. In: Noguera, F.N., Vega Rivera, J.H., García Alderete, A.N., Quesada Avendaño, M. (Eds.), Historia Natural de Chamela. Inst. Biol., Universidad Nacional Autónoma de Mexico, Mexico, pp. 83-97.

Mädel, E., 1962. Die fossilen Euphorbiaceen-hölzer mit besonderer bercksichtigung neuer Funde aus der Oberkreide Sd Afrikas. Senckenberg. Lethaia 43 (4), 283-321.

Magallón-Puebla, S., Cevallos-Ferriz, S.R.S., 1993. A fossil earthstar (Geasteraceae; Gasteromycetes) from the late Cenozoic of Puebla, Mexico. Am. J. Bot. 80, 1162-1167.

Magallón-Puebla, S., Cevallos-Ferriz, S.R.S., 1994a. Latest occurrence of the extinct genus Cedrelospermum (Ulmaceae) in North America: Cedrelospermum manchesteari from Mexico. Rev. Palaeobot. Palynol. 81, 115-128.

Magallón-Puebla, S., Cevallos-Ferriz, S.R.S., 1994b. Fossil legume fruits from Tertiary strata of Puebla, Mexico. Can. J. Bot. 72, $1027-1038$.

Magallón-Puebla, S., Cevallos-Ferriz, S.R.S., 1994c. Eucommia constans n. sp. fruits from upper Cenozoic strata of Puebla Mexico: morphological and anatomical comparison with Eucommia ulmoides Oliver. Int. J. Plant Sci. 155, 80-95.

Mammerickx, J., Klitgord, K.D., 1982. Northern east Pacific rise: evolution from 25 m.y.b.p. to the present. J. Geophys. Res. 87, 6751-6759.

Martínez, M., 1987. Catálogo de Nombres Vulgares y Científicos de Plantas Mexicanas. Fondo de Cultura Económica, Mexico.

Martínez-Cabrera, H.I., 2002. Maderas de la Formación El Cien (Oligoceno-Mioceno) Baja California Sur, Mexico. Determinación taxonómica (Anacardiaceae y Moraceae) y biogeografía histórica de Moraceae. Bachelor Thesis, Universidad Nacional Autónoma de Mexico, Mexico.

Martínez Cabrera, H.I., 2004. Caracteres anatómicos de la madera como indicadores ambientales: el caso de la flora de la Formación El Cien (Oligoceno-Mioceno) Baja California Sur. Master Thesis, Universidad Nacional Autónoma de México, México.

Martínez-Cabrera, H.I., Cevallos-Ferriz, S.R.S., 2004. A new species of Tapirira (Anacardiaceae) from early Miocene sediments of the El Cien Formation, Baja California Sur, Mexico. IAWA J. 25, 103-117.

Martínez-Millán, M., 2000. Biogeografía histórica (Terciario y Cuaternario) de Anacardiaceae con base en caracteres anatómicos de la madera. Bachelor Thesis, Universidad Nacional Autónoma de Mexico, Mexico.

Martínez-Millán, M., 2003. Biogeografia histórica (Terciario) de Anacardiaceae con base en arquitectura foliar. MSc Thesis, Universidad Nacional Autónoma de México, México.

McKenzie, D.P., Morgan, W.J., 1969. Evolution of triple junctions. Nature 224, 125-133.

Meijer, J.J.F., 2000. Fossil wood flora from the Late Cretaceous Aachen Formation. Rev. Palaeobot. Palynol. 112, 297-336.

Mennega, A.M.W., 1987. Wood anatomy of the Euphorbiaceae, in particular of the subfamily Phyllanthoideae. Bot. J. Linn. Soc. 94, 111-126.

Metcalfe, C.R., Chalk, L., 1950. Anatomy of Dicotyledons, vols. 1 and 2. Clarendon Press, Oxford.

Miller, R., 1975. Systematic anatomy of the xylem and comments on the relationships of Flacourtiaceae. J. Arnold Arbor. 56, 20-102.

Mina, U.F., 1957. Bosquejo geológico del territorio sur de la Baja California. Assoc. Mex. Geól. Petrol. 9, 141-269. 
Müller-Stoll, W.R., Mädel, E., 1967. Die fossilen leguminosen-hölzer. Eine revision der mit leguminosen verglichenen fossilen hölzer und beschreibung älterer und neuer arten. Palaeontographica 119B, 95-174.

Ojeda, J., 1959. Resumen de datos estratigráficos y estructurales de la Formación Monterrey que aflora en el área de San Hilario, Baja California. Sur. Revista Geomimet. 100, 51-83.

Prakash, U., 1958. Studies in the Deccan Intertrappean flora, 4: two silicified woods from Madhya Pradesh. The Palaeobotanist 7, $12-20$.

Prakash, U., Tripathi, P.P., 1975. Fossil dicotyledonous woods from Tertiary of eastern India. The Palaeobotanist 22, 51-62.

Prakash, U., Brezinova, D., Awasthi, N., 1974. Fossil woods from the Tertiary of south Bohemia, Czechoslovakia. Palaeontographica 147B, 107-123.

Prakash, U., Bande, M.B., Lalitha, V., 1986. The genus Phyllanthus from Tertiary of India with critical remarks on the nomenclature of fossil woods of Euphorbiaceae. The Paleobotanist 35, 106-114.

Privé, C., 1975. Sur la présence d'un bois fossile d' Euphorbiaceae dans 1'Oligocène du Cantal. Act. $95^{\mathrm{e}}$ Natl. Congr. Soc. Sav. 1970, $111-125$.

Ramírez-Garduño, J.L., 1999. Análisis foliar de Anacardiaceae, Berberidaceae y Salicaceae en Los Ahuehuetes (Oligoceno), Tepexi de Rodríguez, Puebla. MSc Thesis, Universidad Nacional Autónoma de México, México.

Ramírez, J.L., Cevallos-Ferriz, S.R.S., 2002. A diverse assemblage of Anacardiaceae from Oligocene sediments, Tepexi de Rodríguez, Puebla, Mexico. Am. J. Bot. 89, 535-545.

Ramírez, J.L., Cevallos-Ferriz, S.R.S., Silva Pineda, A., 2000. Reconstruction of leaves of two new species of Pseudosmodingium from Oligocene strata of Puebla, Mexico. Int. J. Plant Sci. 161, 509-519.

Reinders-Gouwentak, C.A., 1955. The storied structure-features and the taxonomic rank of the leguminous taxa. Acta Bot. Neerlandica. 4, 460-470.

Rodríguez-de la Rosa, R., Cevallos-Ferriz, S.R.S., 1994. Upper Cretaceous zingiberalean fruits with in situ seeds from southeastern Coahuila, Mexico. Int. J. Plant Sci. 155, 786-805.

Rzedowski, J., 1978. Vegetación de México. Limusa, México.

Schenk, A., 1883. Fossile hoelzer. In: Dunken, W., Zittel, K.A. (Eds.), Beitraege zur geologie und paleontologie der libyschen wsche und der angrenzenden gebiete von AegyptenPalaeontographica Bb., vol. 30 , pp. $1-17$.

Schwennicke, T., 1994. Deep and shallow water phosphorite bearing strata of the upper Oligocene of Baja California, Mexico (San Juan Member, El Cien Formation). Zbl. Geol. Palaont. I, 567-580.

Spackman Jr., W., 1948. A dicotyledonous wood found associated with the Idaho Tepskyas. Ann. Mo. Bot. Gard. 35, 107-116. ter Welle, B.J.H., Koek-Noorman, J., Topper, S.M.C., 1986a. The systematic wood anatomy of Moraceae (Urticales): IV. Genera of the tribe Moreae with urticaceous stamens. IAWA Bull. n.s. 7, 91-128.

ter Welle, B.J.H., Koek-Noorman, J., Topper, S.M.C., 1986b. The systematic wood anatomy of Moraceae (Urticales): V. Genera of the tribe Moreae without urticaceous stamens. IAWA Bull. n.s. 7, 175-192.

Terrazas, S.T., 1994. Wood anatomy of the Anacardiaceae: ecological and phylogenetic interpretation. Unpublished $\mathrm{PhD}$ Thesis, University of North Carolina, U.S.A.

Terrazas, S.T., Wendt, T., 1995. Systematic wood anatomy of the genus Tapirira Aublet (Anacardiaceae) - a numerical approach. Brittonia 47, 109-129.

Thayn, G.F., Tidwell, W.D., 1984. A review of the genus Paraphyllanthoxylon. Rev. Palaeobot. Palynol. 43, 321-335.

Thayn, G.F., Tidwell, W.D., Stokes, W.L., 1983. Flora of the Lower Cretaceous Cedar Mountain Formation of Utah and Colorado: Part I. Paraphyllanthoxylon utahense. Great Basin Nat. 43, 349-402.

Trivedi, B.S., Srivastava, K., 1985. Canarioxylon shahpuraensis from the Deccan Intertrappean beds of Shahpura, District Mandla, India. Geophytology 15, 27-32.

Velasco de León, P., 1999. Estudio paleoecológico de una comunidad del Terciario en el Estado de Puebla. PhD Thesis, Universidad Nacional Autónoma de México, México.

Velasco de León, P., Cevallos-Ferriz, S.R.S., 1997. Leaves of Cercocarpus (Rosaceae) in Tertiary sediments of Tepexi de Rodríguez, Puebla. Am. J. Bot. (Abstracts) 84, 144.

Velasco de León, P., Cevallos-Ferriz, S.R.S., Silva-Pineda, A., 1998. Leaf of Karwinskia axamilpense n. sp. (Rhamnaceae) from Oligocene sediments near Tepexi de Rodríguez, Puebla, Mexico. Can. J. Bot. 76, 410-419.

Wegener, A., 1922. Die Entstehung der Kontinente und Ozeane. Braunschweing, vieweg.

Wheeler, E.A., 1991. Paleocene dicotyledonous trees from Big Bend National Park, Texas: variability in wood types common in the Late Cretaceous and early Tertiary, and ecological inferences. Am. J. Bot. 78, 658-671.

Wheeler, E.A., Pearson, R.G., LaPasha, C.A., Zack, T., Hatley, W., 1986. Computer-aided wood identification. N. C. Agric. Res. Serv. Bull. 474. Raleigh.

Wheeler, E.A., Lee, M., Matten, L.C., 1987. Dicotyledonous woods from the Upper Cretaceous of southern Illinois. Bot. J. Linn. Soc. 94, 111-126.

Wheeler, E.A., McClammer, J., LaPasha, C.A., 1995. Similarities and differences in dicotyledonous woods of the Cretaceous and Paleocene, San Juan Basin, New Mexico, USA. IAWA J. n.s. 16, 223-254. 